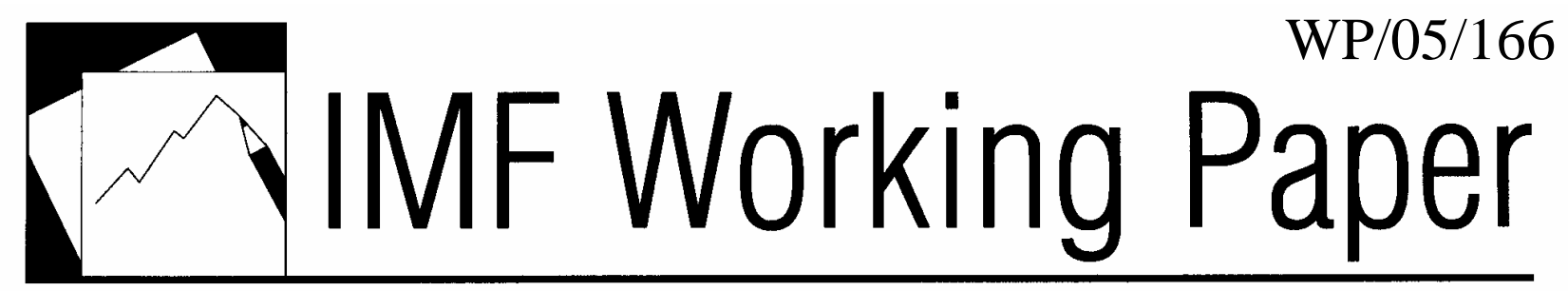

\title{
Access to Bank Credit in Sub-Saharan Africa: Key Issues and Reform Strategies
}

Emilio Sacerdoti 


\title{
IMF Working Paper
}

Monetary and Financial Systems Department

\section{Access to Bank Credit in Sub-Saharan Africa: Key Issues and Reform Strategies}

\author{
Prepared by Emilio Sacerdoti ${ }^{1}$
}

August 2005

\begin{abstract}
This Working Paper should not be reported as representing the views of the IMF. The views expressed in this Working Paper are those of the author(s) and do not necessarily represent those of the IMF or IMF policy. Working Papers describe research in progress by the author(s) and are published to elicit comments and to further debate.

This study discusses issues of access to bank credit in Sub-Saharan Africa, and examines measures that could help facilitate access by the private sector to bank credit. It reviews in particular obstacles to credit small- and medium-scale enterprises and agriculture, and examines progress in the design and implementation of reform measures that are needed to create an institutional environment more supportive of credit activity. It also reviews bank interest rate spreads and profit margins, and their determinants, and compares such spreads with those prevailing in other regions of the world.

JEL Classification Numbers: E44, G21, G28, O23, O55
\end{abstract}

Keywords: Banking systems; Sub-Saharan Africa

Author(s) E-Mail Address: esacerdoti@imf.org

\footnotetext{
${ }^{1}$ I am grateful to Robert Corker for useful comments and suggestions, to participants at the IMF's African Department seminar for helpful discussions, and to Naly Carvalho and Bakar Ould-Abdallah for excellent research assistance.
} 
II. Bank Credit Expansion to the Private Sector in Sub-Saharan Africa: Some Stylized Facts 4

III. Barriers to Financial Intermediation and Reform Action Programs .................................

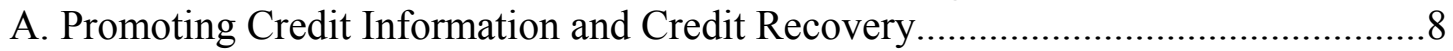

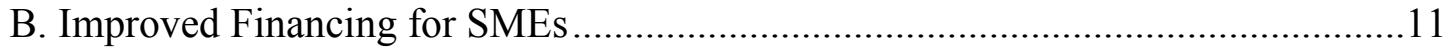

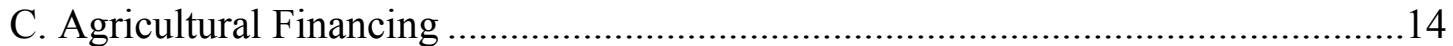

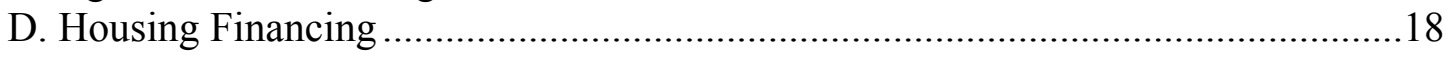

IV. Banking Spreads and Profit Margins ........................................................................ 19

V. Conclusions and Policy Implications.....................................................................20

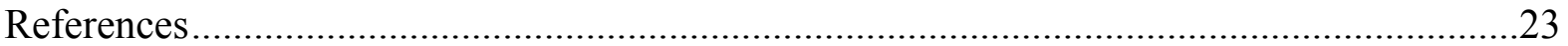

Tables

1. Sub-Saharan Africa: Bank Credit Indicators (Ratios in percent)...................................25

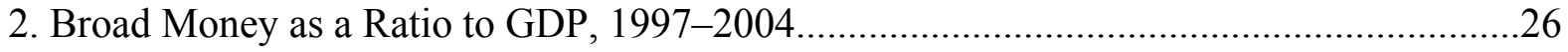

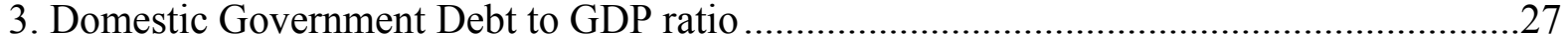

4. Overal Fiscal Balances, Including Grants, 1997-2004 ..................................................28

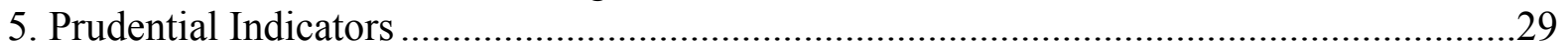

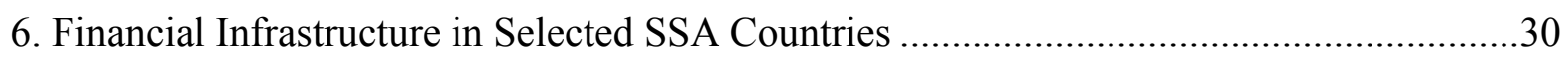

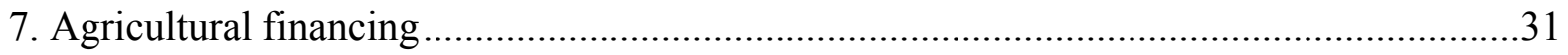

8. Decomposition of Interest Rate Spreads (In percent of assets) …..................................32

9. Banks' Earning and Profitability in Selected Countries outside Africa .............................33

Figures

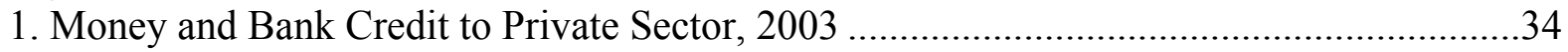

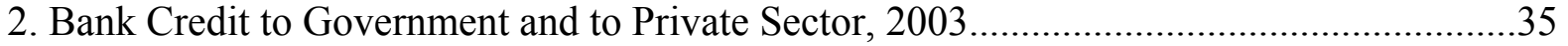

3. Domestic Debt and Bank Credit to Government ...............................................................36

4. Bank Liquidity Ratio and Credit to Private Sector, 2003 .............................................37

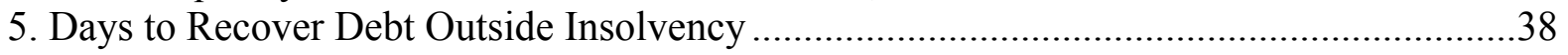




\section{INTRODUCTION}

1. A widespread concern of authorities in Sub-Saharan African countries is that their banking systems are not providing enough support to new economic initiatives and, in particular, to the expansion of small- and medium-scale enterprises (SMEs) and agriculture. It is argued that faster economic growth will not be possible without a deepening of the financial system and, in particular, more support from the banking system. It is noted that banks remain highly liquid in many countries in the subcontinent and reluctant to expand credit other than the most creditworthy borrowers. While microfinance institutions (MFIs) have expanded vigorously in a number of countries, the size of their credit remains limited, so that their support is not on the scale needed for many small projects. Also, the interest rate on microcredits is very high, due to the large administrative costs in relations to their scale of operations. The purpose of this paper is, starting from an overview of the scale of bank credit to the economy in African countries, to review the main barriers to credit expansion to the private sector, the actions that can be taken to address these obstacles, and the progress under way to that end. The paper will also address the issue of credit to the agricultural sector and examine obstacles as well as new initiatives. The paper will also examine to what extent the expansion of MFIs, and improved links between these and the traditional banking system, could contribute to meeting the credit need.

2. The paper examines the role that public finance deficits play in constraining private sector credit, and addresses the question of the magnitude of spreads between lending and deposit rates. A main conclusion is that eliminating the obstacles generated by excessive public deficits and macroeconomic instability is only a first necessary step to promote bank intermediation, but not a sufficient condition for its expansion. Indeed, the improvement of the information, legal and judicial environment is essential in order to create an environment more conducive to credit expansion. The paper notes that central banks can play a more active role in promoting a credit culture, through, inter alia, strengthening credit reporting, credit bureaus, and rating systems. Borrowers can also improve their chances for access to credit by participating in well designed mutual guarantee funds, as is the case in more advanced countries. The paper also underscores that, as regards agricultural credit, credit schemes provided by marketing boards, and similar cooperative schemes, cannot be easily replaced, and may well remain the main venue for providing needed credits for inputs, in view of the absence of real estate titles and other adequate collateral.

3. The organization of the paper is as follows. Section I contains the introduction. Section II reviews the data on bank credit expansion to the private sector in Sub-Saharan Africa, and provide some comparison with other developing countries. It also examines the impact of public sector deficits on private sector credit expansion, and reviews the liquidity situation of banks in a number of Sub-Saharan African countries. It notes that in a number of countries banks remain very liquid, and yet are highly profitable. Section III highlights the mainly institutional barriers that hamper banks credit to the private sector and review reforms of instruments and institutions that have proven useful for credit promotion; it examines in particular the experience regarding credit to SMEs, and agricultural and housing financing. It also reviews the role of MFIs in credits to SMEs and agriculture. Section IV presents a 
comparative analysis of banking interest spreads and profitability. Section V contains the conclusions and policy implications.

\section{Bank Credit Expansion to the Private Sector in Sub-Saharan Africa: Some STYLIZED FACTS}

4. A key characteristic of Sub-Saharan Africa is that the stock of bank credit to the private sector (including nonfinancial public enterprises) remain very low, when compared with the situation in other developing countries. The only notable exceptions are South Africa and Mauritius, which have a well developed financial infrastructure. This reflects low financial intermediation, as measured by the ratio of broad money M2 to GDP, but also a number of other factors, largely of an institutional nature. As indicated in Tables 1 and 2, for most SSA countries the ratio of M2 to GDP in 2003 was in the range of 15 to 30 percent, with only South Africa, Mauritius, and Seychelles recording higher ratios. The ratio of M2 to GDP is strongly associated with the overall economic development of a country, and therefore with per capita income. However, the relation presents significant fluctuations, and is not strictly linear, as can be noted by a comparison of this ratio and per capita income in the 44 SSA countries (Tables 2 and 3). Comparing the ratio of M2 to GDP with that of bank credit to the private sector (including non financial public enterprises) to GDP, it can be noted that there is a linear relation between these two indicators (Figure 1). For most SSA countries the latter ratio is in the range of 10 to 20 percent, but a number of countries have a ratio below 10 percent: among these are countries such as Madagascar, Malawi, Tanzania, Uganda, and Zambia, which also record an M2 to GDP ratio in the lower range for the group.

5. When analyzing the ratio of bank credit to the private sector, a key determinant is often the government deficit, and the amount of financing that the government is seeking from the banking system. Government deficits that have to be financed by domestic resources provide an opportunity for the banking system for a relative safe investment of their deposit base, thereby raising the lending rates, and decreasing the amount of resources channeled to private sector credit. An in depth analysis of the domestic government securitized debt in Sub-Saharan Africa countries is contained in Christensen (2004). This study notes that for a large number of Heavily Indebted Poor Countries (HIPC) the domestic government debt as a share of GDP is modest, as these countries made recourse mostly to external grant and borrowing to fund their public investment requirement. ${ }^{2}$ The domestic government debt to GDP ratio at end- 2000 was however high for Cape Verde, The Gambia, Ghana, Kenya, Namibia, Nigeria, and Zambia where it exceeded 18 percent, with a peak for the Gambia at 31 percent (Table 3). South Africa's and Mauritius's domestic debts are higher, at 41 and 36 percent of GDP, respectively, but can be more easily absorbed owing to a much deeper financial system. Among Heavily Indebted Poor Countries (HIPC), Ethiopia

\footnotetext{
${ }^{2}$ Securitized government debt includes treasury bills, development bonds, and other bonds. The data exclude direct advances from central banks and commercial banks.
} 
stands apart, with a domestic debt to GDP ratio of 42 percent in 2000. Finally, the situation of Seychelles, with a debt-GDP ratio of 102 percent, is very distinct, with the debt held mostly by a very liquid banking system.

6. An important issue is the extent to which the pressure of government domestic financing requirement has led to crowding out of the credit to the private sector. Regression analysis reported in Christensen (2004), covering 27 SSA countries over the period 19802000 , regressing private sector lending on domestic government securitized debt, found evidence of some crowding out: an expansion of domestic debt of 1 percent relative to broad money is associated on average with a decline of the ratio of private sector lending to broad money of 0.15 percent. However, Figure 3, based on the data of Table 3, indicates that the relationship between domestic debt and bank credit to government is not very close. Of the countries quoted in the previous paragraph, with a relative large share of domestic government debt to GDP, only Ethiopia, Mauritius, and Cape Verde have also a high ratio of bank credit to government to GDP, in excess of 12 percent.

7. A closer analysis indicates that there are only few countries in Sub-Saharan Africa in which the pressure of the government domestic financing requirement has contributed to a decline in the ratio of private sector credit to M2; among these are the Gambia, Ghana, Malawi, and Zambia, which in 1997-2001 have registered overall fiscal balances after grants in excess of 4 percent of GDP (Table 4). In Ghana lending to the government at end-2003 represented more than half of the total domestic assets of the banking system, reflecting the large fiscal deficits in the past, and the high reserve requirements that oblige banks to hold at least 35 percent of their deposit liabilities in government securities. In the 2000-03 period the pressure on banks to finance the government has not declined, but a shift is apparent in 2004 . Also in the Gambia, up to the year 2000, financing of the government absorbed more than half of the deposit base of commercial banks, but this ratio has declined sharply since then, to 32 percent at end-2003. In Malawi and Uganda the move of the commercial banks toward allocating a large part of their deposit base to government financing is instead a recent phenomenon; in the former the ratio rose from 16.8 percent at end-2000 to 39 percent at end2003, and in the latter from 35.2 percent at end-2000 to 47.3 at end-2003. In Kenya this ratio has also increased significantly in 2000-03 (from 29.5 percent to 36.7 percent), as the fiscal deficit doubled to 2.3 percent of GDP over this period. A similar increase has occurred in Zambia (from 16.8 percent at end-2000 to 48.9 percent at end-2003), also associated to a rising fiscal deficit.

8. In most other SSA countries the relatively low ratio of bank private sector credit to GDP is not attributable to the government's need for domestic financing, but reflects the low ratio of M2 to GDP, an indicator of financial deepening (Figure 1), and also the high liquidity ratio maintained by the banks, whose propensity to lend remains weak (Figure 4). ${ }^{3}$ Figures 1

\footnotetext{
${ }^{3}$ In Ethiopia the rising ratio between 2000 and 2003 of bank credit to government to deposits reflects has not been a cause of crowding out, but rather is the consequence of the high
} 
and 2 indicate that while there is a marked positive relation between bank credit to the private sector as a share to GDP and the ratio of M2 to GDP, bank credit to private sector does not appear to be inversely related, on average, with the size of credit to government. A typical case is the one faced by the banking system in the franc of the Communaute Financière Africaine (CFA) zone countries. In these countries the banks remain extremely liquid, their financing of the government is modest, and yet credit to the private sector expand sluggishly. Liquid reserves at the central bank, which are in part not remunerated, and short-term foreign assets, held with correspondent abroad, constitute for the banking system of these countries between 30 and 50 percent of their bank deposits. This situation is present in many other countries in the Subcontinent, such as Madagascar, Mozambique, Uganda, where banks tend to be liquid and profitable, while expansion of bank credit to the private sector is Subdued. A more positive development has taken place in Tanzania, where bank credit to the private sector has increased by $2 \frac{1}{2}$ times in real term in the period 2001-04. The ratios of nonperforming loans (NPLs) to total loans fluctuate through countries, but, broadly, after the important bank restructuring that took place in Africa in the late 1980s and early 1990s, banks are reasonably profitable, as measured by the rate of return on equity (Table 5), and inadequate provisioning of NPLs is a problem only for few countries. ${ }^{4}$ The evidence is that across countries banks tend to finance the most solid enterprises, and rather than incurring risks in providing credit to SMEs, they prefer to maintain large deposits, even if not remunerated, at the central banks, or with correspondents abroad at low interest rates.

9. If in SSA bank credit to private sector is generally low as a share of GDP, remaining for most countries below 20 percent, it is interesting to note that this feature is also shared, even if not so acutely, by a number of developing and emerging countries in other regions of the world. In Latin America the limited amount of bank credit to the private sector is a factor of concern in a number of countries. The ratio of this aggregate to GDP in 2003 was well below 20 percent in Mexico, at 20 percent in Peru, below 30 percent in Colombia and Brazil, and at about 30 percent in Costa Rica; the only country with a healthy ratio was Chile, at 62 percent (Table 1). In Asia the ratio is about 30 percent in countries such as India, Sri Lanka and the Philippines, while it is higher than 80 percent in Thailand and Malaysia. Indepth reviews of banking developments in these countries point out that the barriers to larger bank financing of the private sector often reside in limitations to secure lending, weak enforcement of creditor rights, and inadequate debtor information systems. Regulatory

liquidity of the banks, which have been offered an outlet for investment by the government in form of government securities.

${ }^{4}$ Large bank restructuring at significant cost took place in Senegal in 1988-89, Côte d'Ivoire 1988-89, Benin 1988-89, Mali 1989, Niger 1989-90, Nigeria in the late 1980s, Cameroon 1990-97, Kenya 1993-94 and 1998, Madagascar 1996-98, and Tanzania 1996-99. The restructuring process is continuing in Kenya, Tanzania and Zambia. High NPLs, with inadequate provisioning, persist in Ghana; however these adverse factors are cushioned by a wide interest rate spread, leading to comfortable profits for the banking system. 
burdens to nonbank financial intermediation, such as leasing and factoring, are also mentioned as an impediment to larger financing. In some countries, like Brazil, crowding out by the public sector is also an important factor. In Central and Eastern Europe recent developments point to a rapid increase of financial intermediation and credit to private sector, starting however from very low levels at the beginning of the transition period from centralized to market economy. It is noteworthy that even after a number of years in which credit growth to the private sector has been in excess of 20 percent in real terms in most of these countries, the ratio of private sector credit to GDP is still around 30 percent or below for most countries in the region. ${ }^{5}$

\section{BARRIERS TO FINANCIAL INTERMEDIATION AND REFORM ACTION PROGRAMS}

10. The discussion on how to strengthen financial intermediation in SSA countries has come to the fore in recent years, in the context of the Financial Sector Assessment Program (FSAP) exercise, and related Financial System Stability Assessment Reports (FSSA), and of the preparation of Poverty Reduction Strategies that seek to reinvigorate growth and the fight against poverty. With a large number of countries in SSA having reached an acceptable degree of macroeconomic stability, reined in inflation, and contained fiscal deficits - all factors that constitute an obstacle to financial deepening, - the focus has now moved to the institutional and legal weaknesses in these countries which deter to banks to assume more risks, and extend credit to less credit worthy borrowers. Given the large bank failures and restructuring needed in the recent past, the prudence of banks, often Subsidiaries of foreign banks, which have frequently taken over previous banks in difficulties, is not surprising.

11. It is widely recognized that for bank intermediation to deepen it is necessary that: (i) financial information on borrowers is of good quality and controllable; (ii) collateral is sufficiently available to borrowers and enforceable to lenders; (iii) creditor rights are adequately protected, through an effective judicial system and are instruments of conflicts resolution. At the same time, there is a need to: (i) promote more competition among banks; and (ii) develop new markets and products well adapted to meet the financing needs of economic operators.

12. To that end, Fund and Bank advice has centered on a number of recommendation, directed at fostering an improved credit culture. These recommendations can be grouped under the following five categories:

(i) Ensure a more accurate information on the financial status of borrowers, through improved quality of annual accounts and financial statements, professional development of accounting personnel, updating of land and company registries, establishment of credit bureaus, and possible introduction of rating systems.

\footnotetext{
${ }^{5}$ For an analysis of the factors explaining rapid credit growth in the region see Cottarelli, Dell'Arriccia and Vlakova-Hollar (2003) and Hilbers, Otker-Rober, Pazarbasioglu and Johnsen (2005).
} 
(ii) Strengthen claims recovery and collateral realization processes, inter alia through modernization of land titles issuance regimes, acceleration of title issuance, facilitation of foreclosures procedures, and reinforcement of the physical and financial resources of the judiciary system.

(iii) Establish more appropriate bank resolution processes, to protect creditors, and maintain borrowers' discipline.

(iv) Establish new markets and products developments, including development of leasing and factoring, and establishment of mutual guarantee associations.

(v) Promote competition between banks, by encouraging market access, and ensuring better protection of consumers through better information on terms and conditions of loans.

While progress in all these areas is under way in SSA countries, its intensity and speed vary across countries. Many of these improvements require a comprehensive reform process, which is unlikely to be completed quickly. In the section below, the problems and reform strategies in the area of credit information and credit recovery are analyzed, before moving to examine instruments that can facilitate lending to SMEs, agriculture, and housing.

\section{A. Promoting Credit Information and Credit Recovery}

13. To foster a credit culture, it is essential that progress be made in the area of accounting standards, availability and quality of collateral, credit information, and credit recovery. In all these areas, significant progress has yet to be achieved in SSA countries, although reform actions are under way in many countries to address existing weaknesses. A summary of reform actions and measures needed in selected SSA countries is presented in Table 6.

\section{Accounting standards}

14. The ability of borrowers to provide adequate financial statements and the establishment of credible credit bureaus and financial data bases are essential to encourage the expansion of credit, promote competition in the banking systems, and thereby reduce the cost of credit to borrowers. In many countries, banks are reluctant to extend credit to SMEs because of the inability of the borrower to produce formal financial statements and audited accounts. Strengthening accounting and auditing is therefore a key requirement for widening access to banks by SMEs. In many countries, however, the accounting profession is not well regulated, and the quality of accounts vary widely, hampering transparency. Acknowledging the importance to improve the quality of accounting, initiatives are under way in many countries. Thus, in the member countries of the Western African Economic and Monetary Union (WAEMU), a uniform accounting system was adopted in 2001 (Système Comptable Ouest Africain-SYSCOA), which should contribute to strengthen the overall accounting standards in the region. In Tanzania, the regulation of company accounting and auditing practices was modernized through the 2002 Company Act. Improvements in accounting 
standards have been introduced in Uganda and Zambia. Despite these improvements, reliable information on borrowers remains often elusive, and is not shared among lenders.

\section{Registries and credit bureaus}

15. Poor information on borrowers due to accounting weaknesses are compounded by the absence in many countries of reliable and updated company and land registries, the inadequate registries for mortgages and chattel interests, and the absence of well functioning credit bureaus. These deficiencies increase credit risks and costs for banks, and also undermine the competitiveness of the banking system, as borrowers cannot use their track record to secure the best lending terms. Credit information sharing ensures transparency of the borrowers' quality, thereby benefiting good borrowers, while also increasing the cost of defaulting. It also contributes to expand the bankable population of enterprises and households.

\section{Credit bureaus}

16. In advanced countries data bases centralizing information on borrowers are frequently established by the private sector; however, in a number of continental European countries, including France and Italy, these have been established and maintained by central banks. In the WAEMU, the work to establish a Centrale des Bilans is being expedited, to supplement the existing "Centrale des risques" (central credit register). In Kenya, in 2003 an amendment to the Banking Act allowed for information sharing among banks, but other finance providers (building societies, leasing, hire purchase, and factoring companies) have yet to be given access to a common information sharing mechanism. In Tanzania progress toward establishing a credit registry has accelerated in 2004, when banks agreed to set up a credit bureau, which started operations at end-2004. However, it is expected that some time will be needed before it will become a useful tool. In Zambia a credit bureau is being set up by the Bankers' Association, but initially it will include only information on a borrowers' default. More comprehensive information, also on small and medium-scale firms, should be progressively acquired, in order to facilitate the access to the banking system of firms with good credit history. In Uganda the licensing and establishment of a national credit reference bureau is under preparation. The planned credit bureau would cover all institutions supervised by the Bank of Uganda. In Mozambique a public credit registry has been established in 1997, and has operated successfully since then; however, the coverage of borrowers is low; harsher penalties for noncompliance with data Submission requirements, and the expansion to include nonblank financial institutions and other lenders, are considered important to improve the quality of the registry. A rating system of borrowers exist in the WAEMU, as a result of the requirement by the regional central bank that a borrower be rated in order for its bank loans to be eligible for rediscount. However, given the ample liquidity of the system and hence the limited need for rediscounts, banks in recent years have not requested many rating agreements (accord de classement) from the central bank; since end2002 banks are required to Submit rating agreements request for their 50 largest credit users. 


\section{Availability of collateral, reliability of registries, and claim recovery procedures}

17. Claim recovery and collateral realization processes are often very weak in SSA countries. This is a phenomenon common to developing countries in other regional areas as well. This barrier to credit protection is aggravated by the fact that in many countries the issuance of titles, is extremely slow, due to the absence of appropriate procedures for registration of properties, and inadequate resources of property registration offices, Some countries are making efforts to address this problem, by accelerating the issuance of property titles, in particular in the main cities. ${ }^{6}$ Legal impediments exist in some countries to the use of land as collateral; this is still the case in Mozambique, while in Madagascar, foreign entities cannot become owners of real estate, thus preventing foreign owned banks to seize real estate collateral. ${ }^{7}$ In Tanzania the 1999 Land Act established certain limitations on the creation of mortgages, ${ }^{8}$ and excluded foreclosures as an instrument of relief for the lender, thus making mortgages less attractive as collateral than more liquid assets. The Land Act was revised in April 2004 to promote collateralization of land for bank loans and to ease foreclosures regulations Subject to proper notification and with pre-specified timeframe to settle NPLs before collateral is liquidated. These changes however have not had a noticeable impact on bank lending, as the supporting judicial measures have not yet been implemented.

18. While agricultural financing will be the object of a specific section below, it has to be noted that the complex problems of extremely limited agricultural land tenure and registration in many African countries represents a major impediment for long-term financing of agricultural investment. Realistically, the improvement in land registries and the accelerated issuance of land titles will require a sustained effort over a protracted period of time. While collective property of land will continue to impede a generalized issuance of land titles, in particular in the countryside, in urban areas less difficulties should exist as regards issuance of property titles. There is also a need to improve the functioning of company registries, as the unreliability of existing files is a major impediment to the extension of credit. In Uganda the improvement in company registries, which are badly out of date and incomplete, is now a key priority, as indicated in the 2004 FSSA update report.

19. Credit recovery is hampered in many countries by the malfunctioning of the courts, and cumbersome legal and judicial procedures. Figure 5 presents the number of days needed to recover debt outside insolvency for a number of countries (in Maputo it takes on average

\footnotetext{
${ }^{6}$ Examples in this area are initiatives taken in Benin, Tanzania, and Gabon. In many countries much of the real property, even in cities, is not formally registered, i.e. is not formalized by a title; this is the case for instance in Senegal and Côte d'Ivoire, among others.

${ }^{7}$ The law is in the process to be revised to allow foreign banks to hold real estate property, acquired in foreclosures, for a limited period of time.

${ }^{8}$ They include the requirement that mortgages be approved by the Land Commissioner.
} 
540 days, versus 80 days in South Africa). Enforcement of judgments with respects to loans in defaults take in many countries several years, with high recovery costs. Foreclosure and realization of security requires in many countries requires a judgment and order for sale by public auction (this is the case for instance in Ghana). As procedures related to the enforcement of secured interests are very cumbersome in many countries, priority should be given to establishing out of court enforcement procedures or summary enforcement procedures. In most countries insolvency proceeding are very lengthy; for instance, in a country such as Senegal the FSSA update report (2005) notes that they are rarely completed, thereby affecting creditors rights since debt collection procedures are suspended during insolvency procedures. Also in Senegal the claims recovery and collateral realization process is difficult and slow; as a result, 22 percent of the commercial banks' bad debts are older than 10 years, and 35 percent have been on the books for 5 to 10 years. In many countries borrowers adopt a number of delaying tactics, and are facilitated in obtaining injunctions in their favor. ${ }^{9}$ In some countries it is easy for borrowers to block creditors efforts to collect delinquent loans. In Uganda it is reported that there is a strong stigma attached with insolvency proceedings. Recovery fees are high, the number of accountants and lawyers competent in insolvency issues is low, and the Official Receivers Department has inadequate resources. In Uganda proposals have been made to overhaul the formal insolvency system, inter alia with the introduction of a more appropriate corporate rescue procedure; this would facilitate temporary administration, with a moratorium or stay on creditor claims imposed during this period. ${ }^{10}$

20. This short survey indicates that there are major impediments to improve the enforceability of claims, and that extensive efforts are needed to improve the functioning of the judiciary and to institute effective enforcement procedures. In particular there is a need to develop out-of-court enforcement procedures or summary enforcement proceedings; this generally requires the revamping of the legal codes, and may go counter widely accepted cultural principle that tend to favor borrowers in default, in particular regarding long-held real estate property.

\section{B. Improved Financing for SMEs}

21. The dearth of financing for SMEs arises from many factors. Such financing is essentially more risky, and therefore if banks can earn adequate returns by lending to governments and larger established firms, they will have little incentive to embark in more risky loans. Therefore, to stimulate such lending, in addition to the improvements in credit information and credit recovery discussed above, it is also necessary that: (i) governments do

\footnotetext{
${ }^{9}$ This has been noted in the Financial Systems Stability Assessment (FSSA) reports for Senegal, Mozambique, Uganda and Tanzania (see references).

${ }^{10}$ A recommendation to overhaul Uganda's formal insolvency system has been Submitted in September 2004 by the Uganda Law Reform Commission.
} 
not preempt the use of loanable funds; and (ii) adequate competition is maintained in the banking system. In addition, instruments well suited to SMEs financing, such as leasing, should be promoted, making sure that the regulatory and fiscal framework is appropriate. This section also reviews the role that instruments, such as mutual guarantee schemes, can play to facilitate lending to SMEs, and discusses the role of mature MFIs in such lending.

\section{Enhanced competition}

22. With increased competition, some banks will find that their competitive advantage may lie in financing smaller firms. In particular, if Subsidiary of large foreign banks operate in the country, it can be expected that they will concentrate their lending to the larger firms, and those with more trade related operations, which foreign banks may have a competitive advantage to finance. This may induce local banks, possibly with a better knowledge of local conditions, to expand financing of SMEs. It is reported that in Senegal, where banks are very liquid, all major banks have a desk dedicated to SME financing. Increased competition also decreases spreads between lending and deposit rates. While there is widespread complaints that the spread is sticky, existing evidence points out that in fact spread narrow when more banks enter in the market. For instance in Burkina Faso spreads fell considerably (by about 2 basis points) between 1998 and 2000 when the number of banks in the country increased from five to seven. Spreads have been declining in recent years in countries such as Senegal, Cameroon, Cape Verde, and Gabon, reflecting more competition and ample liquidity in the banking system.

\section{Development of leasing}

23. Improved financing of SMEs would also benefit from the development of instruments well suited for small firms, such as leasing, and from the establishment of nonbank intermediaries specialized in this area. The services of leasing companies have clear advantages for firms which lack collateral. Similarly, discounting, factoring and warehousing firms, which provide working capital financing against inventories and other movable assets receivables, are particularly relevant for SMEs in agribusiness. In many countries the development of leasing companies has been hampered by legal and judicial constraints, and lessors have encountered in some countries the same problems as banks in recovering property. For instance, in some countries, such as Tanzania, courts entertain injunctions by borrowers at time of repossession, if the lessee has paid more than 50 percent of the value of the property in question. In Kenya, the tax treatment of leases is Subject to considerable uncertainty, with the revenue commissioner having the authority to change the definition of the lease if the purchase option is executed at the end of the lease period, with potential heavy penalties levied on the lessee; also, the maturity term cannot be extended, and financial leases do not allow the transfer of ownership at the end of the lease for the residual value, making financial leases a less attractive option. ${ }^{11}$ In Uganda the expansion of leasing toward

${ }^{11}$ The weaknesses in the treatment of leases in Tanzania and Kenya have been highlighted in the recent Financial System Stability Assessment (FSSA) reports for these countries. 
small borrowers is hampered by the tax deductibility of capital depreciation by the lessee rather than the lessor. In Senegal and other WAEMU countries the tax treatment of the revenue stream of the lessor, recently modified by to conform to the new accounting system for the region, has to be better specified, to avoid that repayment of principal by the lessee be taxable. It is therefore essential that tax legislation be modernized in a number of African countries, to facilitate the development of leasing.

\section{Mutual credit guarantee schemes}

24. Mutual credit guarantees mechanism have been advocated as well suited for facilitating access to credit by SMEs. Indeed, in many advanced European countries mutual credit guarantees schemes have been established for decades, with positive results; they were the basis of the establishment more than a century ago of the networks of "banques populaires" in France and Italy, which are mutual credit banks. Mutual guarantees groups (MGG), established by members with similar objectives and/or in the same region, or district, can alleviate the difficulty of providing real or personal collateral. They are characterized by solidarity among borrowers, and co-sharing of risks, which become a shared responsibility for the group. A good functioning of these groups requires some homogeneity between members, together with a degree of trust in each other, as they will be called to share the repayment obligation should the beneficiary of a loan fails in its repayment obligations. This is the same principle of "tontines," that have proven successful in many areas of Western Africa. Several mutual guarantee funds exist in Senegal. They are under consideration in Gabon, where a public institution, benefiting from credit lines from multilateral lenders (the Fonds d'Expansion et de Developpement des Petites et Moyennes Entreprises, FODEX) could assist the SMEs to regroup for this purpose, and could also provide additional counter guarantees to strengthen the capital of the funds. A guarantee fund was established in Madagascar after the 2002 prolonged institutional crisis, to encourage banks to extend loans to companies which because of the crisis had suffered Substantial losses of working capital. The fund was constituted by donors, the banking association, and the government, and provided a useful incentive for new loans, that otherwise would not have been made. A guarantee fund for SMEs is also at an advanced stage of preparation design in Tanzania; the purpose is to provide guarantees for loans made through commercial banks, with the government taking a share of the risk. It must be emphasized that mutual guarantee funds must be properly designed and managed, in order to avoid moral hazard on the part of the borrower and of the lender. Due diligence and monitoring function must remain with the lender, and the coverage should not be too high to eliminate the pressure to repay.

\section{The role of MFIs}

25. In a number of countries mature MFIs are beginning to play a role in financing SMEs. ${ }^{12}$ They can have an advantage on traditional banks, as SMEs may be unable to meet

${ }^{12}$ It is to be noted that in Cameroon, a country with an extensive network of MFIs, these have played an important role in SME financing for many years. 
conventional bank criteria such as producing formal financial statements, as compared with cash flow-based lending, scoring techniques, prior lending experience with the client that are often used by successful MFIs. MFIs can use information and risk assessment techniques acquired through dealing with clients that have started as micro-entrepreneurs. A country where the largest MFIs have shown an interest to finance SMEs is Senegal, as noted in the Senegal FSAP update report. Indeed, in Senegal two large MFI networks have plans to create a bank or a financial establishment that would specialize in SME lending. While in some countries, such as Senegal, MFIs have not yet been able to obtain line of credits and mediumand long-term financing from commercial banks, it is notable that in others, such as in Benin, commercial banks have been willing to extend credits to MFIs which have a strong credit recovery record.

26. The gradual transformation of mutual credit institutions in full service banks, with a particular orientation to service SMEs, as has occurred in Europe over the last 200 years, could be an important element to improve access to credit. The experience of Tanzania's National Microfinance Bank (NMB) is interesting in this respect. The bank has the largest branch network in the country; while it has about 750,0000 depositors, it has about 20,000 micro borrowers, with average loan size equivalent to $\$ 400$. There are no data on the amount of SME lending, but the bank seems well positioned to ensure a transition between micro lending and SME lending, given its vast network and the experienced gained in extending small loans.

27. The above analysis indicates that improving access to credit for SMEs depend on a large number of factors, which can be improved through decisive and comprehensive action programs in the SSA countries. Improving the quality of accounting and creditors' information, wider availability of collateral, and strengthened claims and collateral recovery procedures appear to be a key prerequisite. At the same time, increased competition in the banking system, stimulated by new entrants, better regulation of leasing, development of mutual guarantee schemes, strengthening of MFIs are key factors that could increase significantly the flow of resources channeled to meet the credit needs of SMEs.

\section{Agricultural Financing}

28. Developing rural and agricultural finance has been a priority in many countries. Yet, agricultural specialized banks, generally created by the state, have become insolvent in many countries, or had to be rescued at large public cost. In Western Africa, agricultural banks have collapsed through the 1980s in Togo, Benin, Senegal, and Côte d'Ivoire. Agricultural credit in Africa, and in other developing countries, is hampered by a number of factors, including land tenure systems that prevent the use of land as collateral, the absence of physical collateral, the high risk associated with rain-fed agriculture and sharp commodity price fluctuations, and poor transport and communication facilities. However, the experience of successful agricultural exporting countries, such as Côte d'Ivoire, shows that bank financing is plentiful for bringing export crops to the market, and to finance the production and processing phase. Indeed, in the Western African Monetary Union, where a regional interbank market exists, a significant part of the excess liquidity of the banks in the whole 
region has since the early 1990s been employed during the cocoa export campaign to finance the purchase of the crop. Similarly, the cotton marketing companies of the producing countries in the Sahel region ${ }^{13}$ have not encountered difficulties in securing large loans, generally of a syndicated nature, both from local and foreign banks, to finance their purchase of unginned cotton from the farmers, and to provide them fertilizers and pesticide.

29. However, these financing arrangements have been predicated on collateral provided by the export crop, and by a strong marketing structure; these arrangements rely on large wholesalers for Côte d'Ivoire cocoa, and large marketing and ginning companies in the Sahel cotton producing countries, partly state controlled. In the same countries, no financing is available for small-scale production by farmers of cereal crops which are destined for local consumption (corn, millet, and rice). The result is that farmers of these products are forced to sell the entire crop shortly after the harvest, at depressed prices, with intermediaries reaping the reward of the rising price in the following months. In order to correct this situation, a possible strategy would be to promote the establishment of farmers' cooperatives, which would set up warehouses, and would be in a better position to obtain credit with warehouse receipt collateral. Such cooperatives have been set up, for instance, in Madagascar, with the support of multilateral agencies, and have been able to secure adequate bank financing to smoothen the timing of sales, owing to a well-monitored system of warehouse receipt collateral.

30. While in Western Africa there has been adequate provision of working capital financing for export crops, longer-term financing for medium-term agricultural investment has been lacking. A similar situation is prevailing in Kenya with regard to coffee production and exports, with financing available only for bringing the crop to the market, associated with export contracts, but no financing available for long-term upgrading of plantations. It appears that to secure long-term financing, the only realistic mechanism is to organize the sector around major marketing or processing companies, which in turn can provide loans to individual farmers. Thus, in the Sahel cotton producing countries the large marketing companies are a conduit for financing the upgrade of plantations, and for providing extension services and rural road maintenance. Similarly, large agricultural concerns, such as Lonrho which controls the key sugar plantations in Mozambique, and the large sugar companies in Mauritius, can secure needed financing that is on lent to individual farmers.

31. In Benin, an interesting scheme grouping cotton producers for the purpose to obtaining inputs on credit, has been established in 2000 after the dismantling of the country's marketing board. It has achieved relatively good results, but gain is strictly limited to the provision of working capital. The scheme is based on the establishment by the three largest cotton producers organization of a centralized group, "Centrale de Securitisation des Paiements et du Recouvrement" (CSPR). Its function is to ensure that when payment of seed cotton to producers is effected by the ginning companies, input credits extended to producers

${ }^{13}$ Benin, Burkina Faso, Chad, Mali, Niger, Senegal, and Togo. 
by dealers and commercial banks are repaid. This is effected by: (i) registering all loans extended in connection with the delivery of inputs to producers; (ii) monitoring seed cotton procurement and delivery during the marketing season; and (iii) separating the financial flows related to the payments by ginners of seed-cotton in a share for the producer, and a share for the input and credit provider. ${ }^{14}$ This scheme had given very good results in the 2000-01 and 2001-02 cotton campaign; however, in 2002-03 10 percent of the loans were not repaid, for a number of reasons, including the fact that producers borrowed inputs for crops other than cotton, some production was sold outside Benin, and some crop was destroyed by fire in warehouses.

32. The existence of reliable land registries is important to support the process of extending credit. Thus, in Uganda deficiencies in land registries (also present in company registries), reportedly increase the cost of credit, and make it more difficult to obtain it. The 2003 Uganda FSAP report notes that unreliable land registries, together with uncertainties in land titles arising from the nonowner occupiers of the land, and high costs associated with land registry searches and registration of mortgages, are an impediment to extending credit especially to the small farmers. On the other hand, in recent years the largest bank in the country has expanded loans to growers of commercial crops who have a longterm relationship with foreign buyers. This confirms the crucial role that the dimension of agricultural commercial operations, and the existence of a predictable flow of earning, have in determining access to credit, and underlines the importance that small farmers regroup, in order to improve their prospects to access bank credit.

\section{The role of MFIs}

33. Networks of MFIs providing rural financing exist in a number of SSA countries (Table 7), but the financial support they can give to small-scale farmers is limited, and is confined to covering the need for working capital. An in depth analysis of the role of MFIs in Africa, with particular focus on selected countries experiences (Benin, Ghana, Guinea, and Tanzania), is presented in Basu, Blavy, Yulek (2004). The next paragraphs provides a partial survey of country experiences focusing on agricultural financing.

34. In Tanzania there has been a tradition of small-scale agriculture financing, centered on the National Bank of Commerce, which had an extensive network of financing to small

${ }^{14}$ The credit mechanism managed by the CSPR is constituted by two steps. First, when the agricultural campaign starts in February, ginning operators pay 40 percent of the value of their pre-agreed quotas of cotton to the CSPR. This part is put aside to repay the dealers which have financed the purchase of inputs for the previous campaign, and/or directly their commercial banks. At the end of the agricultural campaign in December, producers deliver their cotton production to the ginners, and receive, through the CSPR, the payment of the 60 percent value of their production, corresponding to the part that accrue to them after deducting the cost of inputs. 
farmers. After the restructuring of the bank and its division in three segments in 1999, of which two were privatized, the rural branches network, encompassing 200 branches, was assigned to the newly created National Microfinance Bank; the average size of its loan is small, and the bank hold large amount of liquidity. Rural financing is also provided in Tanzania by: (i) the network of about 400 rural savings and credit cooperatives (SACCO), with a total membership of 83,000 in 2001 , and average loan size of about $\$ 200$; and (ii) the donor-sponsored nongovernmental organization with a total of about 130,000 borrowers. The contribution of these networks to the modernization of agriculture and the financing of needed investment is however very limited, given the small size of the loans.

35. In Kenya the SACCO comprises 113 units, with total assets at end-2003 equivalent to only $\$ 30$ million, or half of 1 percent of the assets of the banking system; average loan size is the equivalent to $\$ 180$; they are considered for regulatory purposes microfinance organization. Clearly, they cannot adequately meet the financing need of the rural sector.

36. In the WAEMU, the largest network of rural mutual credit unions is located in Benin, and is the result of a rehabilitation program that started in 1990 after the collapse of the banking sector and of the "Caisse Nationale du Credit Agricole," the agricultural credit bank. The network is constituted by local agricultural credit unions, federated in a network named "Fédération des Caisses d'Epargne et de Crédit Mutuel" (FECECAM). At end-2002 FECECAM included 101 credit unions, with 386,000 members, total assets equivalent to $\$ 35$ million - equal to that of Kenya, despite an economy 1/3 smaller, - an average loan size of about $\$ 500$, and total loans equivalent to 13 percent of total bank loans in the country.

37. In Senegal agricultural credit unions are also expanding, but have not reached the scale of those in Benin. While no data are available on the share of agricultural credit extended by credit unions, total loans by credit unions represented at end-2003 5 percent of total bank credit. In Mali and Burkina, the share, was higher, respectively at 5.4 and 6.4 percent at end-September 2004, while in Côte d'Ivoire the share was estimated at 2.2 percent. $^{15}$ In Mali and Burkina some rural credit associations networks have incurred in a high rate of defaults, and need to be recapitalized.

38. In Ethiopia out of 22 MFIs, 18 are active in rural areas, and had in 2001 about 2 million clients. Loan outstanding amounted to the equivalent of $\$ 46$ million (Br 350 million or 0.7 percent of GDP), or 2.5 percent of total loans of the banking system; average loan size is equivalent to $\$ 100$. Lending by rural MFIs is supplemented by the

${ }^{15}$ Data for Burkina Faso, Mali, and Côte d'Ivoire originate from a sample of credit unions monitored by the BCEAO, which account for about 90 percent of total credit union operations in these countries. 
agricultural credit of the commercial banks, which in 1999 was estimated at $\mathrm{Br} 490$ million, or 1 percent of GDP. ${ }^{16}$ It is estimated that 70 percent of the rural credit demand is unmet.

39. Despite the expansion in a number of countries of rural MFIs, their size remains inadequate to provide other than modest working capital. Until the scale of operation of small farmers is very modest, land titles are not existing, and the overall credit culture is weak, the provision of credit for capacity expansion will continue to rely on the existence of strong marketing firms, as in a number of Western African countries; these maintain control on the farmers to which they advance inputs, for instance by requiring that their crops be sold to the same marketing agency or firm that has advanced inputs. A similar role to support small farmers can also be played by the larger commercial growers, as in Uganda and Kenya, who are able to obtain bank credit on the basis of established relation with foreign buyers. The alternative would be to establish strong cooperatives of farmers, which could then negotiate in a position of force with the banking system for financing, on the basis, for instance, of warehouse receipt collateral. This is the scheme that has evolved over the last 150 years in Europe, where it has given rise to powerful farmers' groups and farmers' banks. However, the movement toward establishing strong farmers cooperatives and commercially viable farms, with adequate collateral to facilitate the provision of credit, is progressing only slowly in the African countries, as confirmed also by the data presented in Basu and others (2004). This hinders the process of modernizing the sector and increasing farming productivity.

\section{Housing Financing}

40. Housing financing is adversely affected in many countries by the lack of land titles, and/or the slowness in issuing them. Thus, in Ghana most lenders have been deterred to providing housing finance, due also to an inefficient and cumbersome foreclosure process; this has left the Home Financing Company as the sole provider of mortgage, as this company benefits from a more favorable legal framework. The authorities are reviewing this framework, in order to encourage more lending by other financial institutions. In Senegal, the legal context is more favorable to housing financing; thus commercial banks have entered in this sector, which was previously covered mainly by the state-owned "Banque de L'Habitat du Sénégal," and are actively competing to provide loans secured by mortgages, when land titles exist. With the significant expansion of housing finance, banks are stressing the need to establish mechanisms to refinance housing credits. To that end, consideration is being given to creating a regional private mortgage refinancing company, which could issue bonds to refinance banks that provide as a collateral a portfolio of mortgages. At the same time, work should proceed on a legal and regulatory framework to facilitate bank issuance of mortgage bonds, and to promote the securitization of claims, so that banks could sell blocks of mortgages to institutional investors. In Gabon, banks are eager, given their ample liquidity, to provide housing financing secured by mortgages, but this has been hampered by the slowness

\footnotetext{
${ }^{16}$ See International Monetary Fund (2005), The Federal Democratic Republic of Ethiopia, Selected Issue and Statistical Appendix.
} 
in issuing land titles. In Tanzania the process surveying and titling land is now under way, but more than 80 percent of the land is still not titled, hampering the use of land to secure credit. With the revision of the Land Act in 2004 mortgages are Subject to less enforcement constraints, but it remains to be seen whether the recent simplification in foreclosure procedures will be effective in increasing the attractiveness of mortgages as collateral.

41. In conclusion, significant efforts remain to be taken in most SSA countries to develop a viable housing financing sector. Interestingly, in countries such as Senegal where land titles in urban areas are common, and mortgages have developed rapidly, the issue has become, as in more developed financial markets, that of finding the more efficient process to refinancing bank housing loans, so a to secure an adequate flow of resources to the sector.

\section{BANking Spreads ANd Profit MARgins}

42. There is a wide concern that bank spreads are too high in Africa. Analysis conducted in a number of FSSA reports indicate that the causes of the spreads in most SSA banking system are the relatively large share of NPLs, high operating costs, difficulties in obtaining and using collateral, and the absence of efficient judicial procedures to facilitate loan recovery. A detailed analysis of the main determinants of the spreads in Kenya across different categories of banks (state-owned, private domestic, and foreign) shows that spreads are a function of loan loss provisions and operating costs (Table 8). Specifically, state-owned banks have the highest loan-loss provisions, and highest profit margins, which together account for almost two-third of the spread; the higher profit margin on lending reflects the higher write-offs on loans; their overall profitability is much lower, as indicated by the return on assets. The analysis for Senegal, conducted in the recent FSSA update, ${ }^{17}$ indicates that average spreads (calculated from the average lending rate minus the average cost of resources) are slightly lower than for banks of comparable size in Africa (Table 8). Overhead costs absorb more than half of the financial margin, in line with results for similar banks in Africa, but loan-loss provisions are higher. Countries in which spreads are particularly high are Zambia, Mozambique, (19 percent in 2002) and Uganda (19.5 percent in 2003) (Tables 5 and 8). A comparison between Uganda and Kenya (Table 8) shows that in Uganda overhead costs as a percent of assets are much higher ( 9 percent versus 5.1 percent for Kenyan private banks), and this difference almost fully explains the higher interest spreads; in turn the higher overhead reflects heavy investments in physical infrastructures, such as branches and ATMs, undertaken in recent years in order to expand its outreach.

43. The most relevant data for Sub-Saharan Africa, reported in Table 8, are those that refer to small banks, i.e. banks with assets lower than the equivalent of $\$ 1$ billion; only very few banks in Africa have a dimension exceeding \$1 billion (only 1 among the 43 Kenyan banks, for instance), and only in South Africa there are banks with assets exceeding the equivalent of $\$ 10$ billion, classified as large banks. Cross-country comparisons

${ }^{17}$ See Senegal, FSSA update, IMF Country Report No 05/126. 
conducted by the World Bank on 143 countries over the period 1995-2001 show that smaller banks and smaller financial systems have higher overhead costs and net interest margins, relative to total earning assets.

44. There is evidence that increased competition reduces spreads; also, increased competition induces banks with better knowledge of local markets to expand loans to SMEs with beneficial effects on access to credit. The evidence from Burkina Faso, quoted above, is important in this respect.

45. A comparison can be made between financial margins in SSA countries, in Northern African countries such as Tunisia and Morocco, and in Southern European countries (Table 8). In Morocco and Tunisia financial margins as a share of total earning assets, which include both net interest income and noninterest income, are 2/3 lower than in Senegal, in Kenya, and in small banks in Africa, as reported in Table 8. The financial margin in Tunisia (3.7 percent in 2003) is in turn somewhat larger than in banks in Southern European countries such as Portugal (3.3 percent in 2003), and Italy (3.2 percent), but similar to that in Greece. The average dimension of the banks, which is smaller in Africa, is an explanatory factor, because it increases the incidence of operating expenses on total earning assets (6.1 percent of assets for small bank in Africa), versus 3.1 percent in Morocco, 2.3 percent in Tunisia, and about 2 percent on average in Italy, Portugal and Greece. Another factor increasing the average spread is the share of loan loss provisions, in percent of assets, which in Tunisia and Southern Europe is about half than for small banks in Africa.

46. However, it is interesting to note that the ratio of total non interest expenses to financial margin is relatively close in SSA countries to that in Northern African and Southern European countries. Thus, starting from a higher financial margin in SSA countries, and after deducting total noninterest expenses, we arrive to a profit margin (rate of return on assets), which is considerably higher, by about a factor of two, in small banks in Africa, and in Senegal and Kenya, in comparison to banks in Northern Africa and Southern Europe. Similarly, the rate of return on equity is almost the double in African countries. This can be justified by the higher overall risk, but probably reflects also a lower degree of competition. It is noteworthy that the profitability in small African banks (rate of return of 18.3 percent in 2002) appears in line with that of banks in other regions of the world (selected countries in Latin America, Asia and Central and Eastern Europe), as indicated in Table 9.

\section{Conclusions And Policy IMPlications}

47. This study has reviewed developments in bank credit to the private sector in SubSaharan Africa (SSA) and highlighted the barriers to access to bank credit. With the return of most SSA countries to broad financial stability over the past few years, including containment of inflation and government deficit, and the banking systems to a large extent restructured after the difficulties encountered in the 1990s, banks have the resources for supporting an expansion of bank credit to the private sector. Credit expansion remains modest in most countries, however, and the ratio of credit to private sector to GDP low mainly because the institutional framework is not supportive. In particular, information on 
borrowers is inadequate, with weak accounting and auditing standards and limited credit information sharing; the legal, judicial, and regulatory framework governing enforceability of claims and property rights are frequently inadequate, and collateral and real estate registration limited. Instruments such as leasing, which are well adapted to financing of SMEs, are frequently Subject to inadequate regulations, and lessors are exposed to similar difficulties in recovering property.

48. This study has examined the efforts under way in a number of countries to correct for the weaknesses of the institutional framework. However, while certain corrective actions are more readily feasible, such as the creation of credit bureaus, the reinforcement of accounting standards, the updating and strengthening of company registries, improved regulatory framework for leasing, others will require more Substantial efforts, as they involve fundamental institutional revamping. This second group of reforms include correcting the deficiencies in the judicial system, including in the enforceability of claims and recovery collaterals, with the introduction of out-of-court enforcement procedures, and the revamping of the titles system and land registration. The land tenure system, given the tradition of collectively held land, is likely to provide an obstacle to agricultural credit, although this obstacle can be circumvented with improved systems of crop collateral, for instance relying on warehouse receipt collaterals.

49. The study has also reviewed the role that MFIs can play in providing credit to SMEs and agriculture. It has highlighted that in some countries the more mature MFIs appear well adapted to lend to SMEs, and may have a competitive advantage, as they can use risk assessment techniques and information acquired though dealing with clients that began as micro-entrepreneurs. However, to put these advantages to good use would require that MFIs obtain adequate resources through credit lines from banks, and be able to provide credit at rates below those they apply to microcredits.

50. The review of agricultural credit indicates that the provision of credit to small farmers faces major obstacles, due to the limited availability of collateral. Efforts must be made for farmers to regroup in strong cooperatives, which can provide adequate guarantees to banks, as indicated above. A substantial difference is likely to persist between, on one side, large marketing firms and boards, as in Western Africa, or commercial growers with close relations with foreign buyers, as in many Eastern African countries, and, on the other side, the small farmers. For the former, securing credit to finance the current crop does not present difficulties, while for the latter, access to credit, other than from MFIs, which are limited in the size of available lending, remains problematic.

51. The study has reviewed the size of banking spreads and their determinants in a number of countries, on the basis of analysis conducted in FSSA reports. Spreads are high in Africa in part because of the small size of banks, which contributes to higher administrative costs for unit of lending, and because of the higher risks, related to inadequate credit information and deficiency in the enforceability of claims. In some countries spreads have come down, as a result of more competition resulting from new entries to the system. A comparison with spreads in Northern African countries and Southern Europe indicates that in 
these latter countries spreads are on average one third of those in African banks; a part of this difference is due to the different average size of banks. Banks are more profitable, on average, in Africa than in these countries, as would be expected considering the higher overall risk (credit risk and operational risk). However, the higher profitability may also partly reflect less competition; comparison with profitability of banks in countries in Latin America, Asia, and Central and Eastern Europe show that earnings of banks in SSA are not out of line. 


\section{REFERENCES}

Banca d'Italia, 2004, Rapporto Annuale per il 2003, May (Rome).

Banco de Portugal, 2004, Annual Report 2003, (Lisbon).

Bank of Greece, 2004, Report for 2003, (Athens).

A. Basu, , R. Blavy, and M.Yulek, "Microfinance in Africa: Experience and Lessons from selected African Countries," IMF Working Paper 04/174 (Washington: International Monetary Fund).

Central Bank of Tunisia, 2004, Annual Report for 2003, (Tunis).

J. Christensen, 2004,'Domestic Debt Markets in Sub-Saharan Africa,'IMF Working Paper 04/46 (Washington: International Monetary Fund).

C. Cottarelli, G. Dell'Ariccia, and I. Vladkova-Heller, "Early Birds, Late Risers, and Sleeping Beauties: Bank Credit Growth to the Private Sector in Central and Eastern Europe and the Balkans," IMF Working Paper 03/213 (Washington: International Monetary Fund).

P. Hilbers, I. Otker-Robe, C. Pazarbasioglu, and G. Johnsen,'Benign or Malignant: Assessing and Managing Rapid Credit Growth and the Role of Supervisory and Prudential Policies" (unpublished, Washington: International Monetary Fund).

International Monetary Fund, 2002, Gabon, Financial System Stability Assessment, IMF Country Report 02/98 (Washington).

, 2002, Tunisia, Financial System Stability Assessment, IMF

Country Report 02/119 (Washington).

,2003, Uganda, Financial System Stability Assessment, IMF Country Report 03/97 (Washington). , 2003, Morocco, Financial System Stability Assessment, IMF Country Report 03/212 (Washington).

, 2003, Tanzania, Financial System Stability Assessment, IMF Country Report 03/241 (Washington).

,2003, Ghana, Financial System Stability Assessment Update, IMF Country Report 03/396 (Washington).

IMF Country Report 04/52 (Washington). 
, 2005, The Federal Democratic Republic of Ethiopia, Selected Issue and Statistical Appendix, IMF Country Report 05/28 (Washington).

, 2005, Senegal, Financial System Stability Assessment Update, IMF Country Report 05/126 (Washington).

World Bank, 2004, Benin, Financial Sector Review, May (Washington). 
Table 1. Sub-Saharan Africa: Bank Credit Indicators (Ratios in percent)

\begin{tabular}{|c|c|c|c|c|c|c|c|c|}
\hline \multirow{2}{*}{ SSA countries } & & $\begin{array}{r}\text { Bank Cr } \\
\text { Sectora } \\
\text { Pub. E } \\
\text { of whi }\end{array}$ & $\begin{array}{l}\text { o Private } \\
\text { on Fin. } \\
\text { GDP } \\
\text { red to }\end{array}$ & $\begin{array}{c}\text { Bank Credit } \\
\text { to Gov to } \\
\text { GDP }\end{array}$ & \multirow[t]{2}{*}{$\begin{array}{c}\text { M2 to GDP } \\
1 /\end{array}$} & \multirow[t]{2}{*}{$\begin{array}{c}\text { Bank } \\
\text { Liquidity } \\
\text { Ratio 2/ } \\
\end{array}$} & $\begin{array}{l}\text { Bank Credit to } \\
\text { Priv. Sector and } \\
\text { NFPE to Bank } \\
\text { Deposits }\end{array}$ & $\begin{array}{c}\text { Bank Credit to } \\
\text { Gov. to Bank } \\
\text { Deposits }\end{array}$ \\
\hline & & & & & & & & \\
\hline Benin & 2003 & 15.7 & -- & 1.2 & 22.0 & 63.2 & 82.6 & 6.7 \\
\hline Burkina & 2003 & 13.8 & -- & 1.3 & 19.2 & 52.0 & 92.0 & 8.5 \\
\hline Cameroon & 2003 & 11.5 & 1.3 & 1.9 & 19.4 & 31.3 & 79.7 & 11.7 \\
\hline Chad & 2003 & 6.3 & 1.9 & 0.8 & 11.7 & 55.3 & 136.0 & 17.5 \\
\hline Cote d'Ivoire & 2002 & 14.8 & -- & 3.7 & 29.3 & 27.6 & 98.4 & 24.2 \\
\hline Ethiopia & 2003 & 24.3 & 1.5 & 15.8 & 59.1 & 47.0 & 52.4 & 41.8 \\
\hline Gabon & 2003 & 11.1 & 0.3 & 3.0 & 16.8 & 37.4 & 81.4 & 22.5 \\
\hline Gambia & 2003 & 19.2 & -- & 6.4 & 44.7 & 44.0 & 51.6 & 32.3 \\
\hline Ghana & 2003 & 14.7 & 3 & 9.4 & 30.4 & 24.8 & 72.0 & 45.8 \\
\hline Kenya & 2003 & 20.3 & 0.6 & 12.6 & 40.3 & 16.7 & 59.1 & 36.7 \\
\hline Madagascar & 2003 & 8.8 & -- & 5.3 & 23.4 & 29.7 & 37.5 & 22.7 \\
\hline Malawi & 2003 & 5.9 & 0.2 & 6.4 & 20.8 & 20.0 & 36.1 & 39.2 \\
\hline Mali & 2003 & 18.7 & -- & 0.6 & 29.7 & 55.1 & 108.1 & 3.2 \\
\hline Mauritius & 2003 & 56.1 & -- & 20.5 & 83.2 & 16.4 & 72.6 & 26.5 \\
\hline Mozambique & 2003 & 13.9 & 11.7 & 4.1 & 31.4 & 31.3 & 50.4 & 17.2 \\
\hline Namibia & 2003 & 51.6 & & 5.2 & 42.1 & 32.0 & 135.3 & 13.9 \\
\hline Nigeria & 2003 & 15.7 & -- & 5.3 & 26.4 & 59.8 & 88.4 & 29.8 \\
\hline Senegal & 2003 & 21.1 & -- & 1.9 & 30.0 & 47.4 & 84.2 & 7.4 \\
\hline South Africa & 2003 & 82.7 & -- & 6.9 & 62.6 & 23.0 & 139.4 & 10.8 \\
\hline Tanzania & 2003 & 7.6 & -- & 3.0 & 22.3 & 49.7 & 44.5 & 17.5 \\
\hline Uganda & 2003 & 7.6 & 1.7 & 7.0 & 19.0 & 33.5 & 51.5 & 47.3 \\
\hline Zambia & 2003 & 6.8 & -- & 8.7 & 17.8 & 50.7 & 38.4 & 48.9 \\
\hline Zimbabwe & 2001 & 19.8 & -- & 6.8 & 21.9 & 24.8 & $\ldots$ & $\ldots$ \\
\hline \multicolumn{9}{|c|}{ Selected Other Countries } \\
\hline Morocco & 2003 & 56 & -- & 18.4 & 92.1 & 15.5 & 74.8 & 24.8 \\
\hline Tunisia & 2003 & 60.4 & -- & 5.2 & 56 & 10.3 & 129.6 & 8.4 \\
\hline Mexico & 2003 & 16.8 & 0.5 & 14.1 & 52.75 & 61.9 & 52.1 & 42.1 \\
\hline Chile & 2003 & 61.7 & 0.3 & 0.7 & 56.6 & 29.4 & 114.5 & 1.2 \\
\hline Peru & 2003 & 20.8 & -- & 2.8 & 29.7 & 38.5 & 87.4 & 14.7 \\
\hline Brazil & 2003 & 28.1 & 0.1 & 20.5 & 31.6 & 55.8 & 124.4 & 90.8 \\
\hline Costa Rica & 2003 & 31.3 & -- & 6.5 & 63.6 & 22.7 & 83.3 & 17.3 \\
\hline Colombia & 2003 & 27.4 & 1 & 11.1 & 32.8 & 37.3 & 71.2 & 29.4 \\
\hline Philippines & 2003 & 34.5 & 3.9 & 14.8 & 56.9 & 30.6 & 68.4 & 30.3 \\
\hline Sri Lanka & 2003 & 32.1 & 2.1 & 7.4 & 40.8 & 25.0 & 89.4 & 20.5 \\
\hline India & 2003 & 31.8 & $\ldots$ & 22.9 & 63.5 & 5.5 & 60.5 & 43.5 \\
\hline Thailand & 2003 & 81.8 & 2.5 & 5.0 & 96.8 & 23.2 & 95.4 & 5.8 \\
\hline Malaysia & 2003 & 97.4 & 0.8 & 7.0 & 100.3 & 30.4 & 106.8 & 7.7 \\
\hline Hungary & 2004 & 46.9 & $\ldots$ & 10.8 & 48.1 & 39.6 & 101.2 & 26.0 \\
\hline Poland & 2003 & 29.0 & $\ldots$ & 11.8 & 42.7 & 29.1 & 79.2 & 32.1 \\
\hline Czech Republic & 2004 & 32.2 & .../ & 16.9 & 70.0 & 54.1 & 52.5 & 27.6 \\
\hline Estonia & 2003 & 33.3 & 0.2 & 2.2 & 40.0 & 54.2 & 97.4 & 6.6 \\
\hline Romania & 2003 & 11.1 & 1.6 & 1.4 & 24.4 & 50.6 & 52.0 & 6.5 \\
\hline Bulgaria & 2003 & 27.3 & $\ldots$ & 5.9 & 48.1 & 38.6 & 82.7 & 18.1 \\
\hline
\end{tabular}

Sources: IMF, International Financial Statistics

1/ For Mexico M4a in the national definition, which includes money market instruments issued by banks. For Brazil, including money market mutual funds. For Chile, including money market instruments issued by banks. For South Africa, M3 in the national definition, which includes money market instruments issued by banks.

2/ Defined as liquid reserves, including reserve requirements, plus foreign assets of banking institutions over demand and time deposits of such institutions. For Mexico and Chile the denominator includes also money market instruments. 
Table 2. Broad Money As a Ratio to GDP, 1997-2004 (In percent of GDP)

\begin{tabular}{|c|c|c|c|c|c|}
\hline & $1997-2001$ & 2001 & 2002 & 2003 & 2004 \\
\hline \multicolumn{6}{|l|}{ Oil producing countries } \\
\hline Angola & 19.0 & 21.2 & 22.8 & 17.5 & 15.8 \\
\hline Cameroon & 14.9 & 17.3 & 20.6 & 19.3 & 19.0 \\
\hline Chad & 11.9 & 12.4 & 13.5 & 12.0 & 8.8 \\
\hline Congo, Rep. of & 14.4 & 12.6 & 13.9 & 13.7 & 12.4 \\
\hline Côte d'Ivoire & 24.6 & 26.0 & 33.0 & 27.3 & 27.3 \\
\hline Equatorial Guinea & 6.5 & 5.6 & 7.4 & 8.7 & 8.7 \\
\hline Gabon & 13.6 & 14.8 & 15.9 & 15.5 & 14.4 \\
\hline Nigeria & 19.1 & 19.4 & 23.4 & 21.5 & 20.7 \\
\hline São Tomé and Príncipe & 35.3 & 42.0 & 43.2 & 52.1 & 47.3 \\
\hline \multicolumn{6}{|l|}{ Nonoil producing countries } \\
\hline Benin & 29.2 & 34.1 & 30.3 & 28.3 & 27.9 \\
\hline Botswana & 27.9 & 31.8 & 27.7 & 28.7 & 28.7 \\
\hline Burkina Faso & 21.5 & 20.3 & 19.2 & 20.4 & 20.4 \\
\hline Burundi & 19.0 & 20.2 & 24.1 & 26.9 & 27.3 \\
\hline Cape Verde & 63.7 & 64.5 & 68.5 & 68.4 & 70.5 \\
\hline Central African Republic & 17.0 & 15.5 & 14.4 & 13.8 & 13.9 \\
\hline Comoros & 20.5 & 27.5 & 28.5 & 25.2 & 23.5 \\
\hline Congo, Dem. Rep. of & 6.2 & 5.0 & 4.7 & 5.1 & 6.5 \\
\hline Ethiopia & 41.9 & 45.4 & 53.2 & 53.4 & 49.3 \\
\hline Gambia, The & 32.1 & 36.1 & 43.5 & 45.9 & 44.3 \\
\hline Ghana & 24.9 & 26.9 & 31.4 & 32.0 & 32.7 \\
\hline Guinea & 10.3 & 11.3 & 12.6 & 15.0 & 17.4 \\
\hline Guinea-Bissau & 34.2 & 48.2 & 61.5 & 71.5 & 80.3 \\
\hline Kenya & 44.2 & 36.7 & 36.4 & 36.2 & 34.4 \\
\hline Lesotho & 32.0 & 31.2 & 28.1 & 26.4 & 26.5 \\
\hline Madagascar & 19.4 & 22.1 & 23.3 & 23.0 & 20.1 \\
\hline Malawi & 15.5 & 14.9 & 18.3 & 20.5 & 22.5 \\
\hline Mali & 21.1 & 22.0 & 26.9 & 29.7 & 31.3 \\
\hline Mauritius & 76.2 & 77.6 & 80.5 & 82.4 & 87.6 \\
\hline Mozambique & 24.6 & 31.4 & 31.9 & 31.4 & 28.8 \\
\hline Namibia & 38.8 & 36.1 & 39.4 & 42.2 & 43.4 \\
\hline Niger & 8.5 & 9.6 & 9.0 & 7.4 & 9.0 \\
\hline Rwanda & 16.9 & 17.3 & 17.6 & 18.5 & 17.2 \\
\hline Senegal & 24.1 & 27.1 & 28.1 & 30.0 & 29.8 \\
\hline Seychelles & 89.0 & 101.8 & 108.8 & 111.4 & 114.0 \\
\hline Sierra Leone & 15.9 & 18.2 & 19.3 & 20.2 & 18.3 \\
\hline South Africa & 56.8 & 58.4 & 59.9 & 62.6 & 65.3 \\
\hline Swaziland & 24.2 & 21.2 & 20.7 & 20.6 & 20.7 \\
\hline Tanzania & 14.1 & 13.3 & 14.1 & 14.6 & 15.7 \\
\hline Togo & 24.3 & 25.8 & 23.9 & 26.0 & 26.0 \\
\hline Uganda & 14.2 & 15.8 & 18.7 & 20.0 & 19.6 \\
\hline Zambia & 20.1 & 21.0 & 22.3 & 21.8 & 22.5 \\
\hline Zimbabwe & 36.5 & 33.6 & 37.2 & 58.8 & 44.6 \\
\hline Sub-Saharan Africa & 37.8 & 37.3 & 38.4 & 41.2 & 42.3 \\
\hline Excluding Nigeria and South Africa & 25.4 & 26.1 & 28.8 & 28.0 & 26.4 \\
\hline CFA Franc zone & 19.2 & 20.3 & 22.7 & 21.7 & 21.0 \\
\hline WAEMU & 23.1 & 24.8 & 27.5 & 26.1 & 26.4 \\
\hline CEMAC & 14.0 & 14.7 & 16.7 & 16.0 & 14.6 \\
\hline SADC & 48.3 & 48.2 & 47.7 & 53.2 & 55.2 \\
\hline COMESA & 31.6 & 31.1 & 33.7 & 34.4 & 31.4 \\
\hline Oil producing countries & 18.6 & 19.3 & 22.9 & 20.4 & 19.3 \\
\hline Nonoil producing countries & 44.0 & 44.1 & 44.1 & 49.1 & 51.5 \\
\hline HIPC (completion point countries) & 22.5 & 24.3 & 26.3 & 26.9 & 26.9 \\
\hline Fixed exchange rate regime & 24.3 & 25.5 & 29.3 & 27.8 & 25.1 \\
\hline Floating exchange rate regime & 41.5 & 40.7 & 42.0 & 45.0 & 46.9 \\
\hline
\end{tabular}

Sources: IMF, African Department database, February 24, 2005; and WEO database, February 24, 2005. 
Table 3. Domestic Government Debt to GDP Ratios for Selected Sub-Saharan African Countries

\begin{tabular}{|c|c|c|c|}
\hline Country & $\begin{array}{c}\text { Domestic Debt/GDP } \\
\text { (in percent, 2000) }\end{array}$ & $\begin{array}{c}\text { Bank credit to gov. } \\
2003 \\
\end{array}$ & $\begin{array}{c}\text { GDP per capita } \\
\text { (in US dollars, 2000) }\end{array}$ \\
\hline Benin & 5.8 & 1.2 & 362 \\
\hline Burundi & 7.3 & 1.2 & 141 \\
\hline \multicolumn{4}{|l|}{ Burkina } \\
\hline Faso & 18.0 & 1.3 & 216 \\
\hline Cape Verde & 25.7 & 22.3 & 1519 \\
\hline Cameroon & 18.7 & 1.9 & 615 \\
\hline Côte d'Ivoire & 16.3 & 3.7 & 669 \\
\hline Ethiopia & 42.2 & 15.8 & 97 \\
\hline Gabon & 8.7 & 3.0 & 3970 \\
\hline Gambia, The & 31.5 & 6.4 & 371 \\
\hline Ghana & 28.9 & 9.4 & 413 \\
\hline Kenya & 21.7 & 12.6 & 328 \\
\hline Lesotho & 11.4 & 11.5 & 551 \\
\hline Madagascar & 11.4 & 5.3 & 249 \\
\hline Malawi & 10.7 & 6.4 & 169 \\
\hline Mauritius & 35.9 & 20.5 & 3820 \\
\hline Mozambique & 3.8 & 4.1 & 209 \\
\hline Namibia & 18.7 & 5.2 & 2408 \\
\hline Niger & 18.5 & 0.8 & 161 \\
\hline Nigeria & 21.5 & 5.3 & 254 \\
\hline Rwanda & 11.7 & 2.1 & 242 \\
\hline Senegal & 6.7 & 1.9 & 466 \\
\hline Seychelles & 101.7 & 87.8 & 7727 \\
\hline Sierra Leone & 10.3 & 4.8 & 147 \\
\hline South Africa & 41.5 & 6.9 & 3985 \\
\hline Swaziland & 0.8 & 1.9 & 1476 \\
\hline Tanzania & 14.6 & 3.0 & 260 \\
\hline Togo & 24.2 & 0.6 & 268 \\
\hline Uganda & 4.9 & 7.0 & 348 \\
\hline Zambia & 19.3 & 8.7 & 392 \\
\hline Zimbabwe & 52.1 & 6.8 & 644 \\
\hline Average & 21.5 & 9.0 & 1083 \\
\hline HIPC & 16.0 & 4.5 & 305 \\
\hline Non-HIPC & 30.9 & 16.7 & 2426 \\
\hline
\end{tabular}

Sources: IMF Staff Reports, Statistical Appendices 
Table 4. Overal Fiscal Balances Including Grants, 1997-2004 (In percent of GDP)

\begin{tabular}{|c|c|c|c|c|c|}
\hline & $1997-2001$ & 2001 & 2002 & 2003 & 2004 \\
\hline \multicolumn{6}{|l|}{ Oil producing countries } \\
\hline Angola & -14.1 & -1.6 & -9.3 & -7.5 & -1.4 \\
\hline Cameroon & -0.4 & 2.4 & 1.6 & 2.0 & 0.4 \\
\hline Chad & -5.3 & -5.3 & -5.9 & -6.2 & -2.2 \\
\hline Congo, Rep. of & -6.9 & -0.7 & -8.1 & 0.4 & 5.4 \\
\hline Côte d'Ivoire & -1.6 & 1.0 & -1.7 & -2.5 & -1.5 \\
\hline Equatorial Guinea & 5.5 & 16.7 & 17.0 & 5.8 & 12.8 \\
\hline Gabon & 0.7 & 3.2 & 3.5 & 7.4 & 7.9 \\
\hline Nigeria & -2.8 & -4.9 & -4.2 & -1.5 & 8.2 \\
\hline São Tomé and Príncipe & -24.0 & -20.4 & -17.2 & -17.0 & -26.1 \\
\hline \multicolumn{6}{|l|}{ Nonoil producing countries } \\
\hline Benin & 0.2 & -1.5 & -2.4 & -2.6 & -2.1 \\
\hline Botswana & 1.8 & -1.4 & -3.7 & -1.1 & -1.9 \\
\hline Burkina Faso & -3.2 & -3.9 & -4.8 & -2.9 & -4.4 \\
\hline Burundi & -4.8 & -5.2 & -1.4 & -6.3 & -0.4 \\
\hline Cape Verde & -10.6 & -4.6 & -2.5 & -3.2 & -2.9 \\
\hline Central African Republic & -0.9 & -0.9 & -1.2 & -3.1 & -1.6 \\
\hline Comoros & -2.9 & -3.6 & -5.1 & -4.1 & -2.7 \\
\hline Congo, Dem. Rep. of & -5.0 & -1.7 & -2.7 & -4.7 & -3.9 \\
\hline Ethiopia & -6.8 & -5.5 & -9.3 & -8.4 & -4.5 \\
\hline Gambia, The & -5.5 & -13.9 & -4.6 & -4.7 & -3.6 \\
\hline Ghana & -8.4 & -7.7 & -5.0 & -3.5 & -2.4 \\
\hline Guinea & -2.8 & -4.1 & -4.4 & -5.1 & -3.1 \\
\hline Guinea-Bissau & -12.4 & -11.7 & -11.5 & -13.8 & -5.5 \\
\hline Kenya & -1.1 & -2.4 & -3.4 & -1.8 & -1.5 \\
\hline Lesotho & -3.8 & 0.6 & -4.2 & 0.7 & 3.2 \\
\hline Madagascar & -3.6 & -4.3 & -5.5 & -4.2 & -3.5 \\
\hline Malawi & -5.7 & -7.4 & -11.6 & -6.6 & -5.2 \\
\hline Mali & -2.9 & -4.1 & -4.3 & -2.2 & -4.1 \\
\hline Mauritius & -4.8 & -5.7 & -6.0 & -6.0 & -5.4 \\
\hline Mozambique & -3.8 & -6.5 & -8.2 & -4.5 & -4.9 \\
\hline Namibia & -3.2 & -3.8 & -3.7 & -6.9 & -3.4 \\
\hline Niger & -3.6 & -3.2 & -2.8 & -2.7 & -2.7 \\
\hline Rwanda & -2.0 & -1.3 & -1.9 & -2.5 & -0.3 \\
\hline Senegal & -0.7 & -2.5 & -0.1 & -1.4 & -2.7 \\
\hline Seychelles & -12.5 & -12.3 & -18.7 & 1.4 & 0.9 \\
\hline Sierra Leone & -9.0 & -8.8 & -8.3 & -7.6 & -5.8 \\
\hline South Africa & -2.4 & -1.5 & -1.2 & -2.0 & -2.9 \\
\hline Swaziland & -0.5 & -2.7 & -4.2 & -3.1 & -2.7 \\
\hline Tanzania & -1.0 & -1.2 & -1.0 & -1.4 & -3.0 \\
\hline Togo & -2.8 & -0.4 & -0.4 & 2.5 & 1.3 \\
\hline Uganda & -3.0 & -2.6 & -5.3 & -4.3 & -1.7 \\
\hline Zambia & -4.4 & -7.2 & -5.1 & -6.0 & -3.0 \\
\hline Zimbabwe & -8.7 & -7.0 & -2.7 & -0.2 & -5.3 \\
\hline Sub-Saharan Africa & -3.0 & -2.6 & -2.8 & -2.2 & -0.8 \\
\hline Excluding Nigeria and South Africa & -3.7 & -2.7 & -3.5 & -2.7 & -1.6 \\
\hline CFA Franc zone & -1.4 & 0.3 & -0.7 & -0.3 & 0.4 \\
\hline WAEMU & -1.9 & -1.5 & -2.2 & -2.2 & -2.4 \\
\hline CEMAC & -0.9 & 2.5 & 1.2 & 2.3 & 3.6 \\
\hline SADC & -3.2 & -2.4 & -2.5 & -2.6 & -2.9 \\
\hline COMESA & -5.5 & -4.2 & -4.9 & -4.6 & -2.8 \\
\hline Oil producing countries & -3.2 & -2.2 & -3.2 & -1.4 & 4.7 \\
\hline Nonoil producing countries & -3.0 & -2.8 & -2.7 & -2.5 & -2.9 \\
\hline HIPC (completion point countries) & -3.6 & -3.8 & -4.3 & -3.4 & -3.2 \\
\hline Fixed exchange rate regime & -2.4 & -1.6 & -1.9 & -0.7 & -0.4 \\
\hline Floating exchange rate regime & -3.2 & -2.9 & -3.2 & -2.7 & -0.9 \\
\hline
\end{tabular}

Sources: IMF, African Department database, February 24, 2005; and WEO database, February 24, 2005 


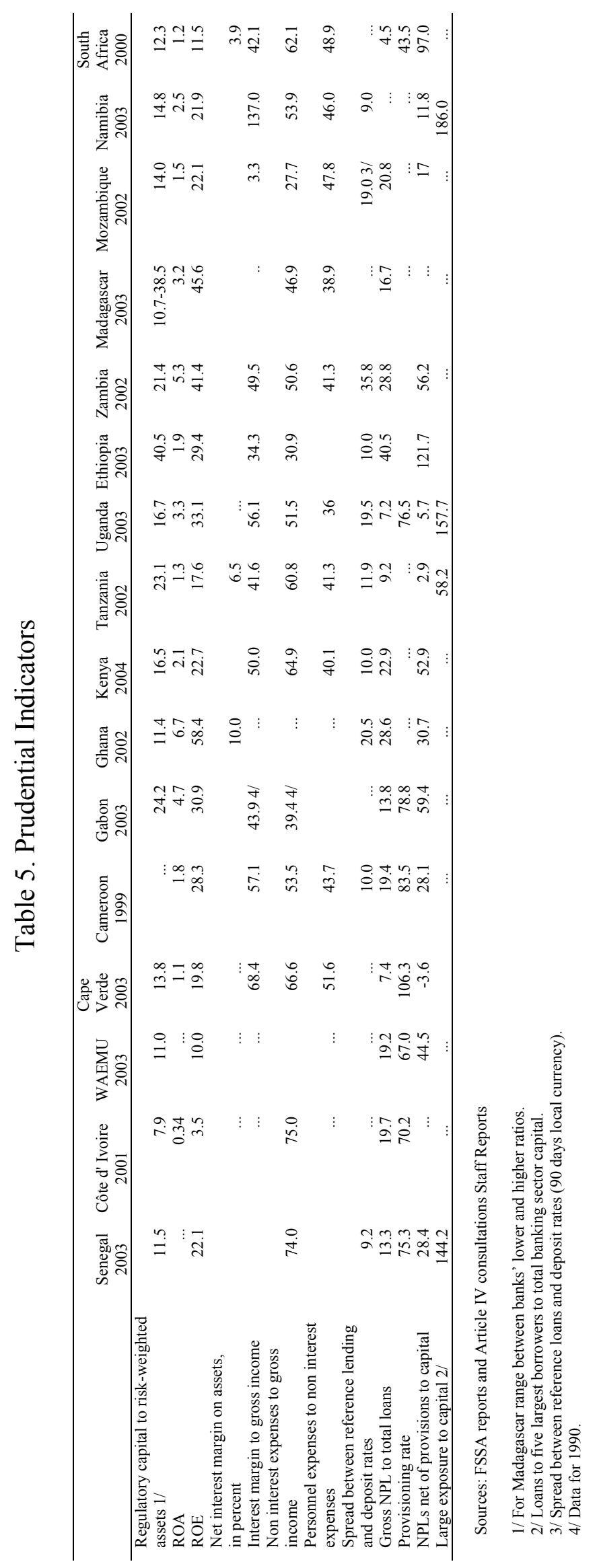




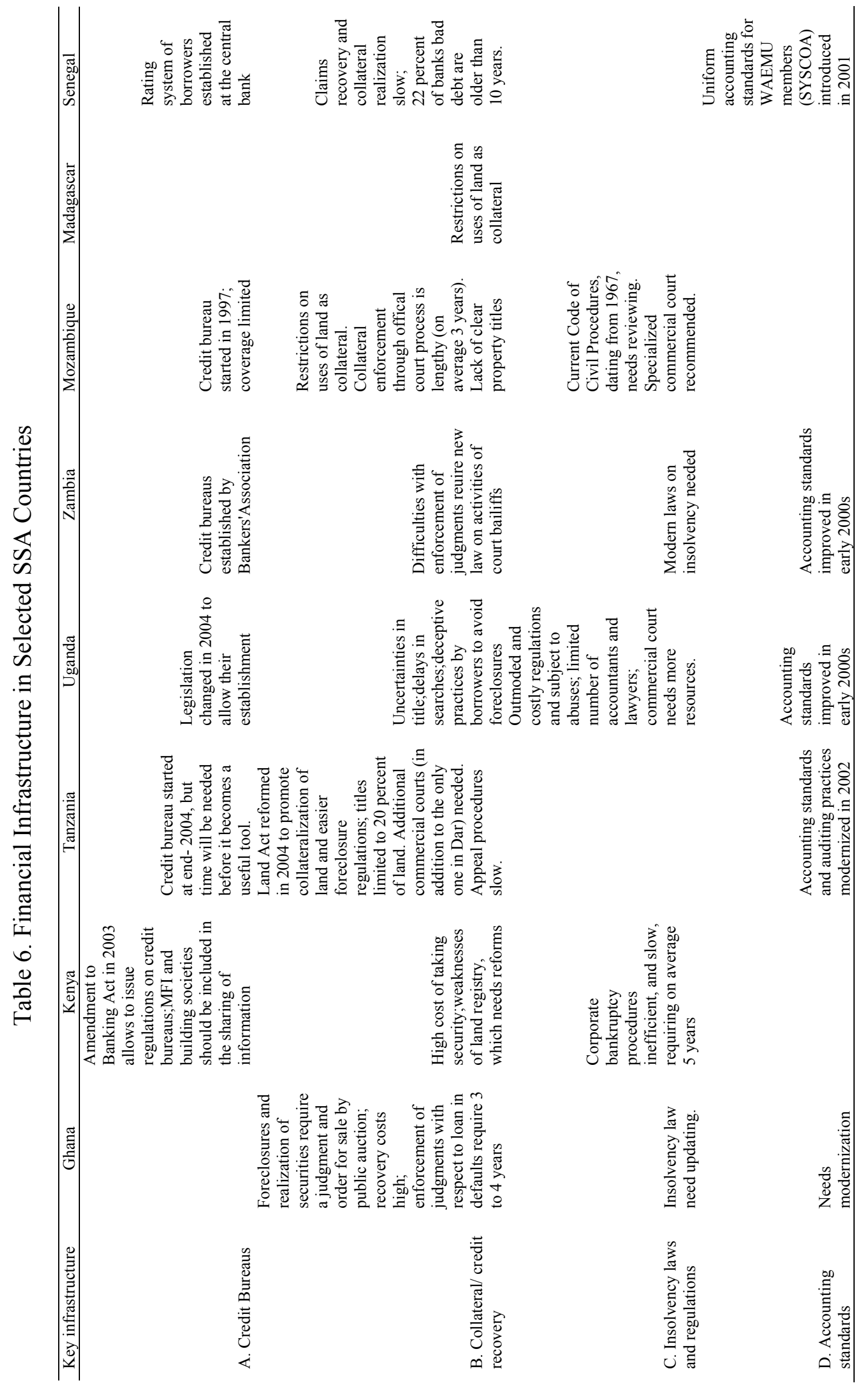




\section{Table 7. Agricultural Financing}

\begin{tabular}{|c|c|c|c|c|c|}
\hline & $\begin{array}{l}\text { number of } \\
\text { institutions: }\end{array}$ & $\begin{array}{c}\text { number of } \\
\text { clients/members }\end{array}$ & $\begin{array}{c}\text { averag } \\
\text { (US\$ } \\
\text { equivalent) }\end{array}$ & $\begin{array}{l}\text { pan amount } \\
\text { percent of per } \\
\text { capita } \\
\text { GDP }\end{array}$ & $\begin{array}{c}\text { Agricultural } \\
\text { credit as a } \\
\text { share of total } \\
\text { bank loans }\end{array}$ \\
\hline Kenya (Dec.2002) & & & & & \\
\hline Rural SACCOs $1 /$ & 113 & 501,000 & 180 & 55 & 10 \\
\hline Tanzania (2001) & & & & & \\
\hline Rural SACCOs 1/ & 400 & 83,000 & 230 & 86 & 14 \\
\hline Branches of NMB 2/ & 108 & & & & \\
\hline Zambia & & & & & \\
\hline National Savings and & & & & & \\
\hline Credit Bank & & & & & \\
\hline Rural microfinance institutions & & & & & \\
\hline Uganda (Dec.2003) & & & & & \\
\hline $\begin{array}{l}\text { Total SACCOs (rural and } \\
\text { urban) }\end{array}$ & 74 & 80,900 & 234 & 94 & 11 \\
\hline Ethiopia (2003) & & & & & \\
\hline Rural Microfinance Institutions & 18 & $2,000,000$ & 100 & 88 & 2.5 \\
\hline $\begin{array}{l}\text { Commercial banks agricultural } \\
\text { credit }\end{array}$ & 8 & $\cdots$ & $\ldots$ & $\ldots$ & 3.0 \\
\hline $\begin{array}{l}\text { Benin (2003) } \\
\text { Rural mutual credit }\end{array}$ & & & & & \\
\hline associations & 101 & 386,000 & 550 & 91 & 13 \\
\hline $\begin{array}{l}\text { Mali (2003) } \\
\text { Rural mutual credit } \\
\text { associations }\end{array}$ & & & & & \\
\hline Senegal (2003) & & & & & \\
\hline $\begin{array}{l}\text { Total mutual credit associations } \\
\text { Rural mutual credit }\end{array}$ & 305 & 510,833 & $\ldots$ & $\ldots$ & $\ldots$ \\
\hline associations & $\ldots$ & $\ldots$ & $\cdots$ & $\cdots$ & $\cdots$ \\
\hline Côte d'Ivoire (2001) & & & & & \\
\hline Total mutual credit associations & 68 & 360,000 & $\ldots$ & $\ldots$ & $\ldots$ \\
\hline Cameroon (2000) & & & & & \\
\hline Total mutual credit associations & 656 & 200,000 & $\ldots$ & $\ldots$ & $\ldots$ \\
\hline $\begin{array}{l}\text { Rural mutual credit association } \\
\text { 1/ SACCOs: savings and credit c } \\
\text { 2/ NMB: National Microfinance }\end{array}$ & $\begin{array}{ll} & \cdots \\
\text { peratives } & \\
\text { ank } & \end{array}$ & $\ldots$ & $\ldots$ & $\ldots$ & $\ldots$ \\
\hline
\end{tabular}

Sources: Cameroon, Kenya, Senegal, Tanzania,Uganda, Zambia: FSSA Reports and FSSA Updates reports. Benin: World Bank Financial Sector Review, May 2004; Ethiopia: Selected Issues paper for 2004. 


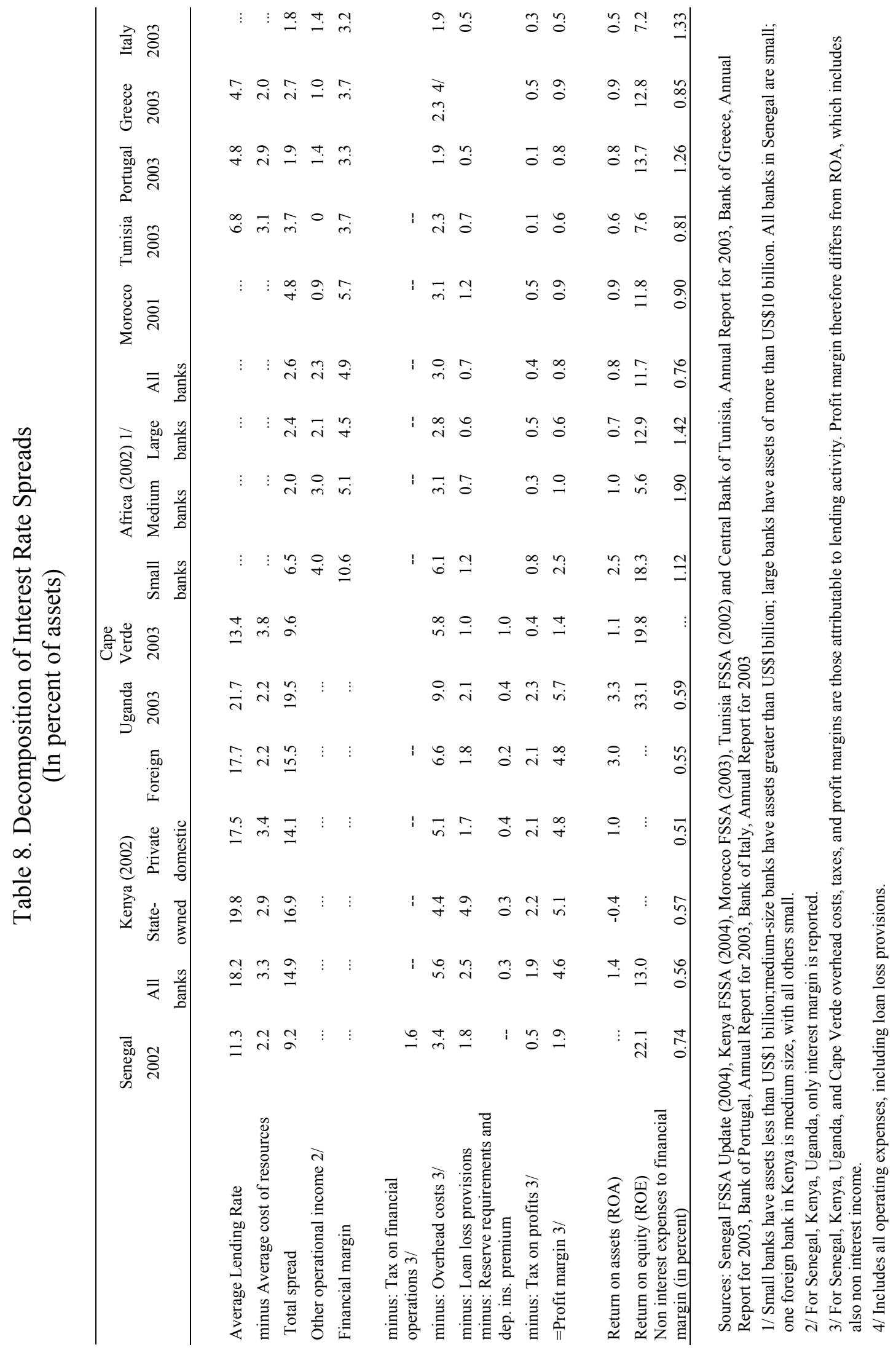




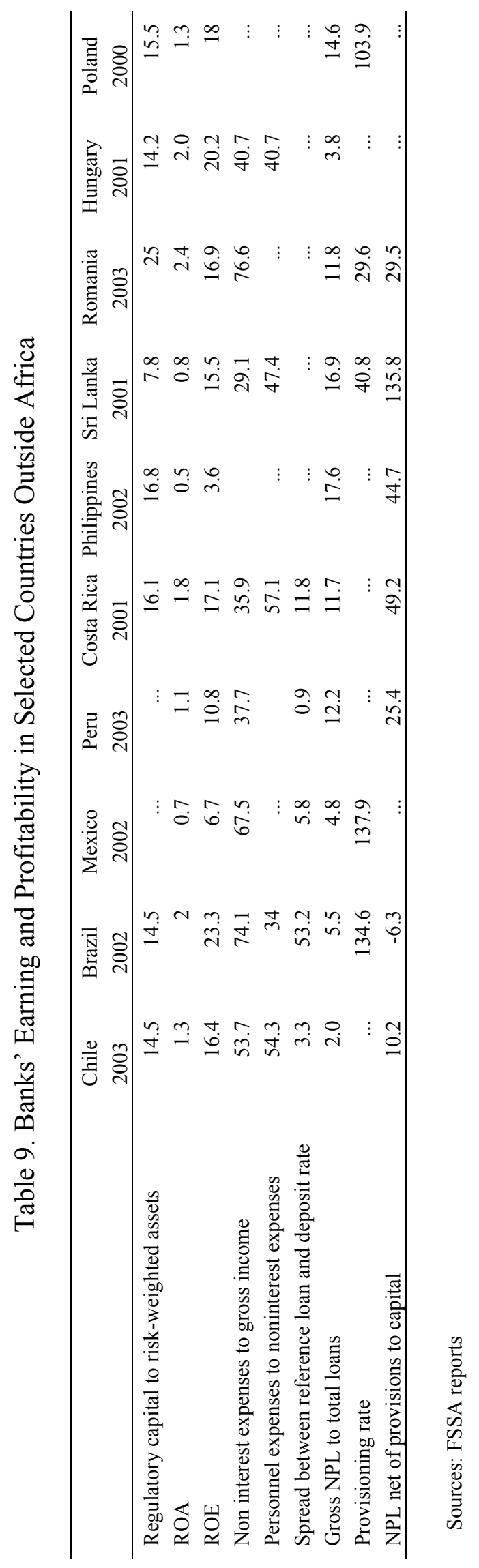


Figure 1. Money and Bank Credit to Private Sector, 2003 (in percent of GDP)

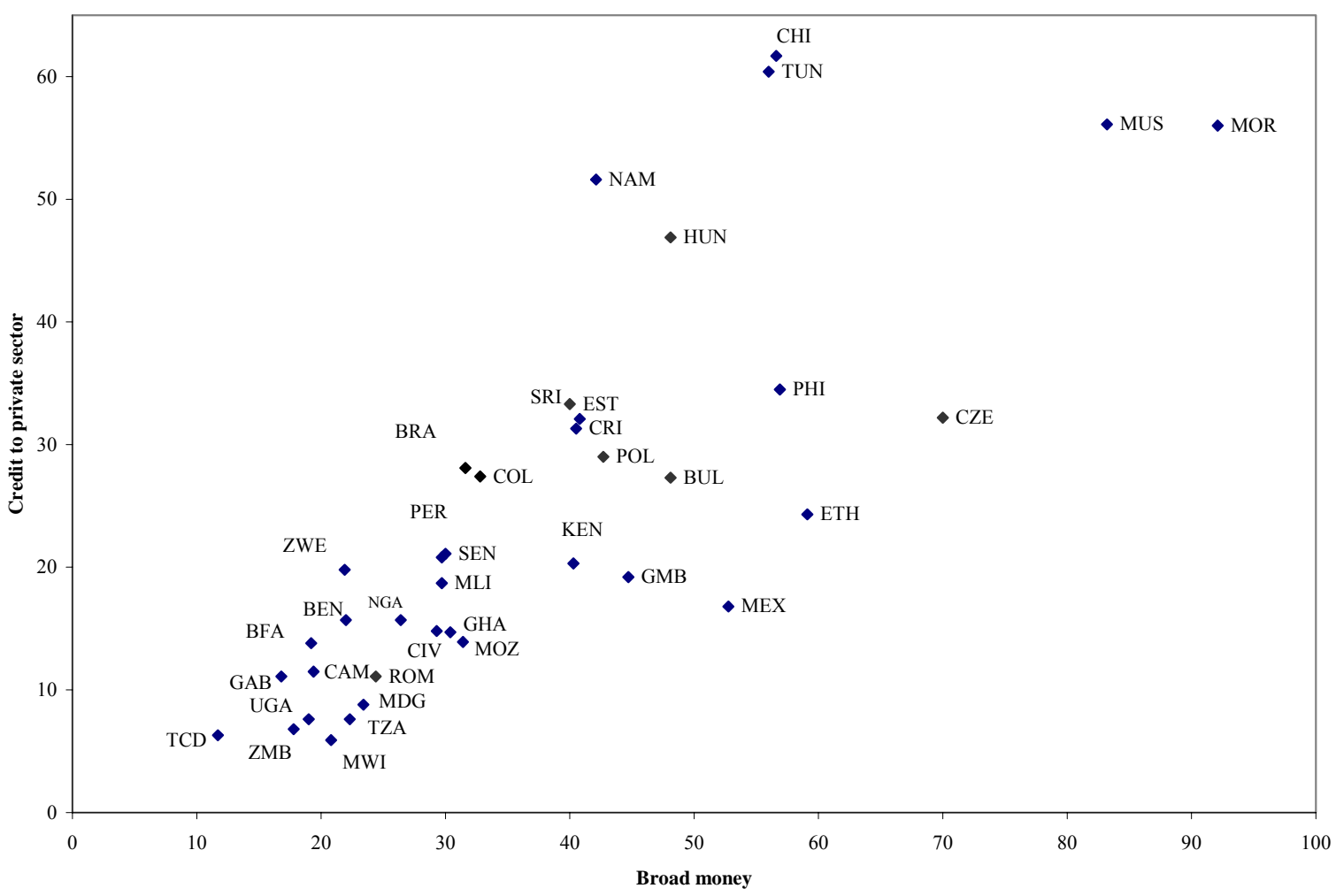

Source: Table 1. 
Figure 2. Bank Credit to Government and to Private Sector, 2003 (In percent of GDP)

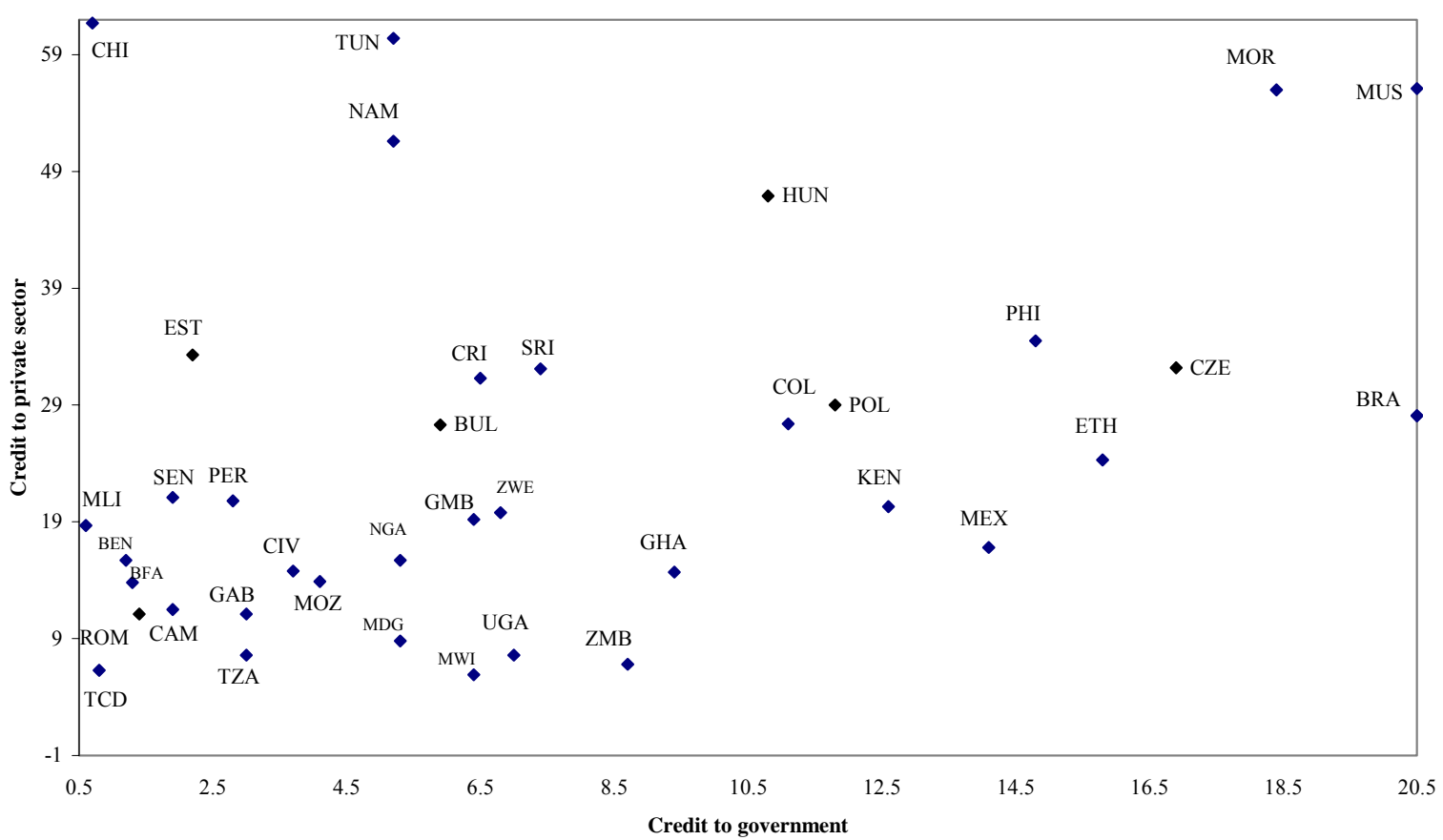

Source: Table 1. 
Figure 3. Domestic Debt and Bank Credit to Government (in percent of GDP)

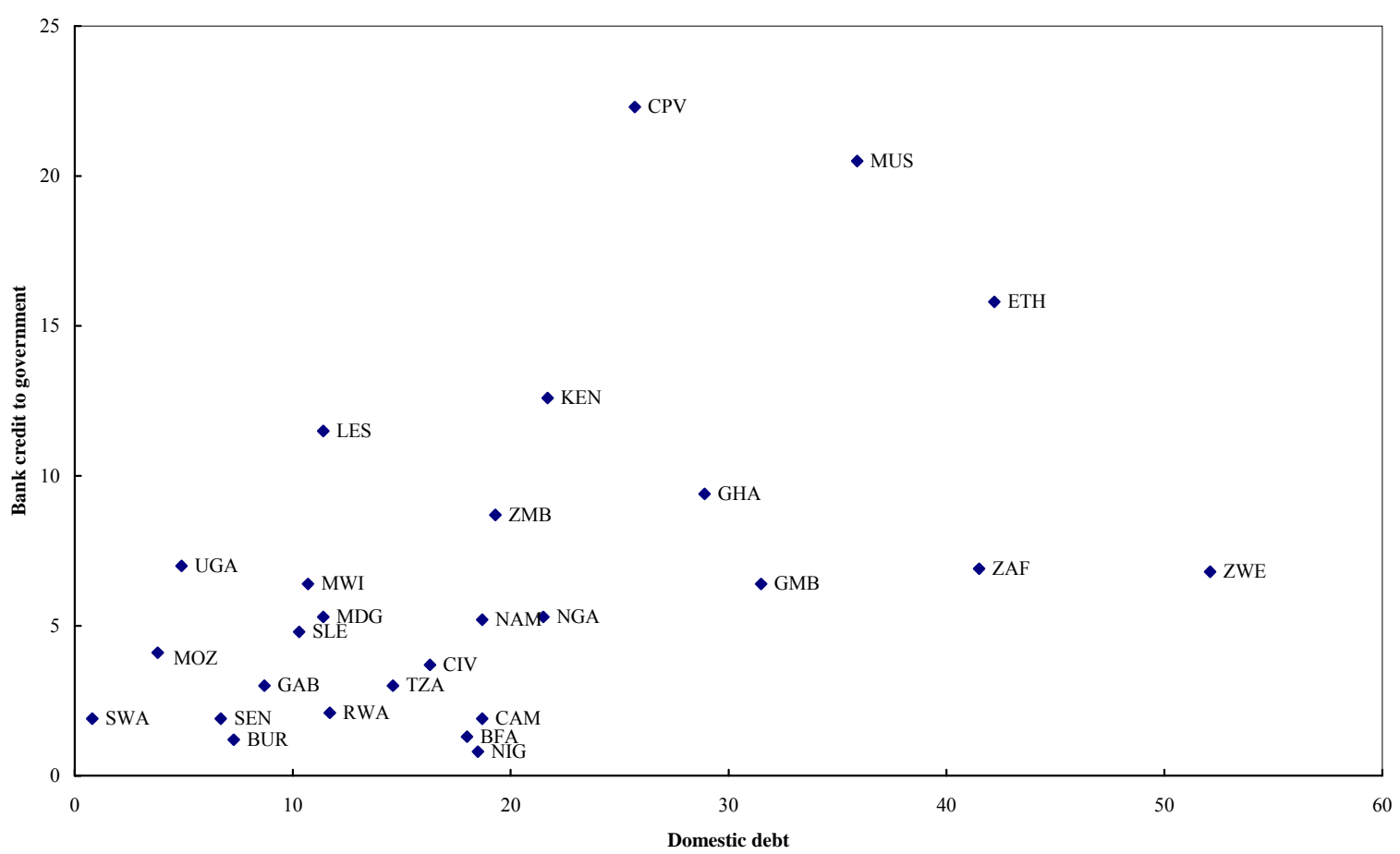

Sources: Tables 1 and 3. 
Figure 4. Bank Liquidity Ratio and Credit to Private Sector, 2003

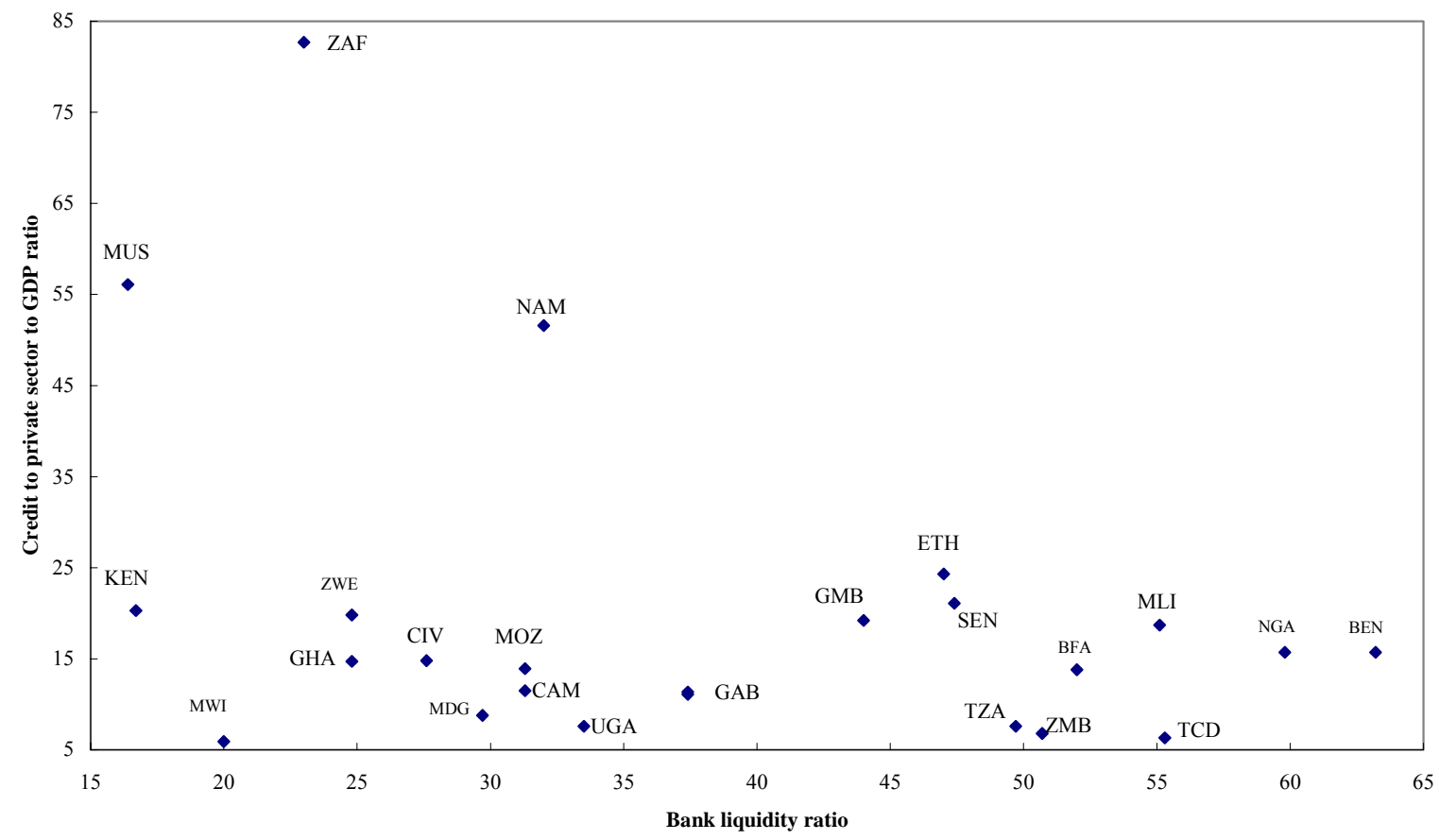

Source: Table 1 
Figure 5. Days to Recover Debt Outside Insolvency

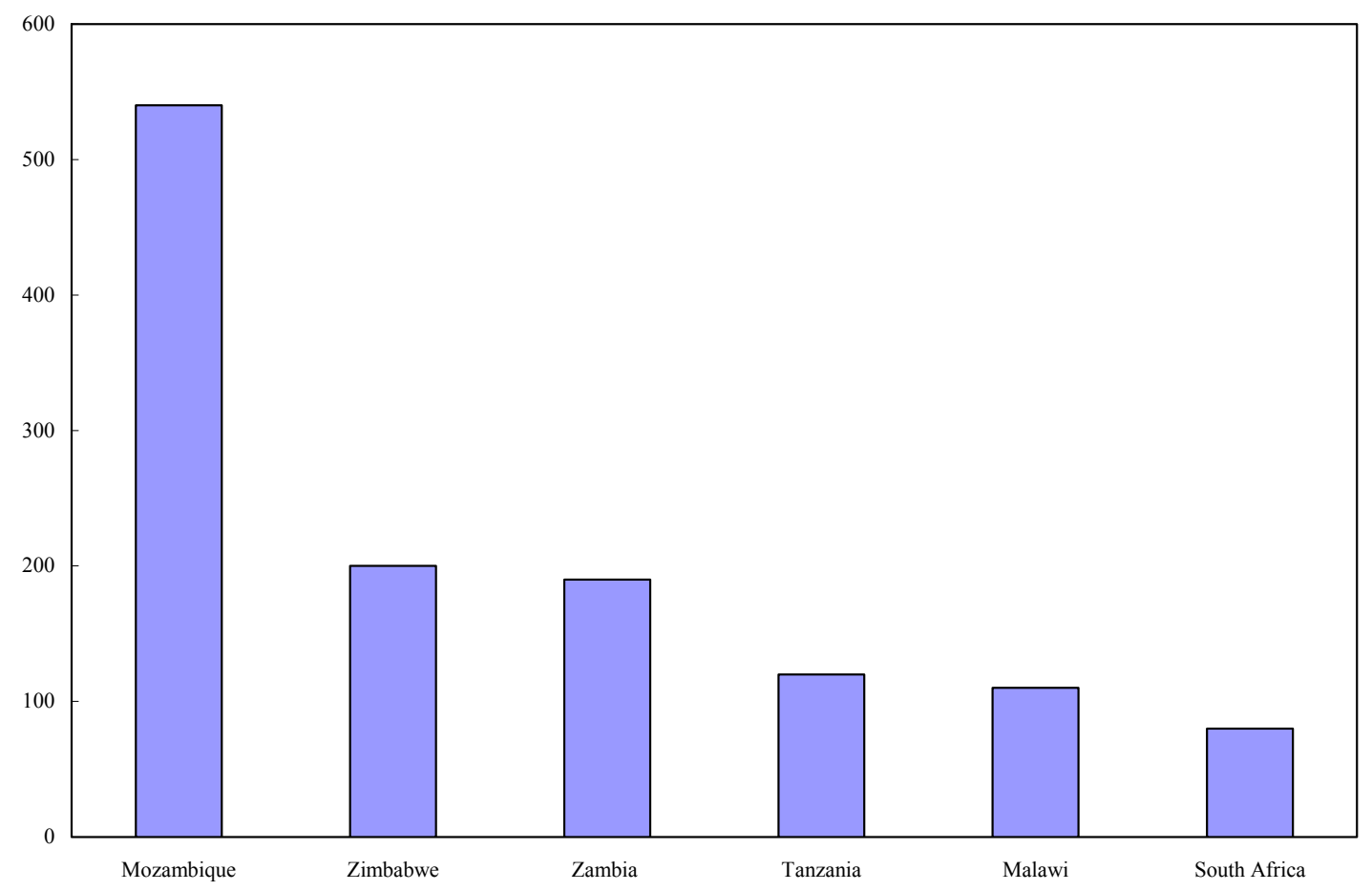

Source: FSSA reports 